\title{
Wat verwachten werkgevers van HBO afgestudeerden?
}

Citation for published version (APA):

Allen, J., Meng, C., \& van der Velden, R. (2016). Wat verwachten werkgevers van HBO afgestudeerden? ROA. ROA Reports No. 001 https://doi.org/10.26481/umarep.2016001

Document status and date:

Published: 01/01/2016

DOI:

10.26481/umarep.2016001

Document Version:

Publisher's PDF, also known as Version of record

\section{Please check the document version of this publication:}

- A submitted manuscript is the version of the article upon submission and before peer-review. There can be important differences between the submitted version and the official published version of record.

People interested in the research are advised to contact the author for the final version of the publication, or visit the DOI to the publisher's website.

- The final author version and the galley proof are versions of the publication after peer review.

- The final published version features the final layout of the paper including the volume, issue and page numbers.

Link to publication

\footnotetext{
General rights rights.

- You may freely distribute the URL identifying the publication in the public portal. please follow below link for the End User Agreement:

www.umlib.nl/taverne-license

Take down policy

If you believe that this document breaches copyright please contact us at:

repository@maastrichtuniversity.nl

providing details and we will investigate your claim.
}

Copyright and moral rights for the publications made accessible in the public portal are retained by the authors and/or other copyright owners and it is a condition of accessing publications that users recognise and abide by the legal requirements associated with these

- Users may download and print one copy of any publication from the public portal for the purpose of private study or research.

- You may not further distribute the material or use it for any profit-making activity or commercial gain

If the publication is distributed under the terms of Article $25 \mathrm{fa}$ of the Dutch Copyright Act, indicated by the "Taverne" license above, 


\section{WAT VERWACHTEN WERKGEVERS VAN HBO AFGESTUDEERDEN?}

ROA-R-2016/1

Jim Allen

Christoph Meng

Rolf van der Velden 


\section{Colofon}

(C) Researchcentrum voor Onderwijs en Arbeidsmarkt (ROA). Niets uit deze uitgave mag op enige manier worden verveelvoudigd zonder voorafgaande schriftelijke toestemming van de directeur van het ROA.

\section{Researchcentrum voor Onderwijs en Arbeidsmarkt}

School of Business and Economics

Maastricht University

\section{Vormgeving}

ROA secretariaat, Maastricht

\section{Verkoop}

Researchcentrum voor Onderwijs en Arbeidsmarkt email: secretary-roa-sbe@maastrichtuniversity.nl

website: www.roa.nl

ISBN: 978-90-5321-544-9 


\section{INHOUD}

Management samenvatting

01 Inleiding

02 Uitkomsten van de HBO-monitor

2.1 Kans op werk in kerndomein

2.2 Verschillen naar baan- en bedrijfskenmerken

03 Vignettenonderzoek onder werkgevers

3.1 Beschrijving van het werkgeversbestand

3.2 De voorkeur voor cv-attributen

3.3 De voorkeur voor competenties

3.4 Verschillen in voorkeuren naar organisatie- en functiekenmerken

04 Conclusies

Literatuur 



\section{MANAGEMENT SAMENVATTING}

\section{Vakkennis loont}

Zowel vanuit het perspectief van werkgevers als volgens afgestudeerden blijkt een goed niveau van vakkennis zeer belangrijk. Van alle competenties blijkt dit de belangrijkste voorspeller voor het hebben van werk dat goed bij het niveau en de richting van de HBO opleiding past één tot twee jaar na afstuderen. Het is dan ook geen verrassing dat professionele expertise dé competentie is waarvoor over de hele linie werkgevers zelf de sterkste voorkeur tonen. Werkgevers willen voorkomen dat ze iemand in huis halen met een laag niveau aan vakkennis en -vaardigheden, en hechten bovendien veel waarde aan het aannemen van afgestudeerden die op dit punt als excellent te bestempelen zijn.

\section{Zorg voor een goede een mix van competenties}

De voorkeur van werkgevers voor een hoog niveau aan vakkennis betekent niet dat andere competenties er helemaal niet toedoen voor arbeidsmarktsucces. Ook meer generieke competenties zoals algemene academische vaardigheden, sociale vaardigheden, commerciële vaardigheden en innovatievermogen zijn belangrijk voor een succesvolle arbeidsmarktintrede. Interessant hierbij is dat afgestudeerden en werkgevers van mening verschillen voor wat betreft welke generieke competenties belangrijk zijn. Uit de HBO-Monitor komt naar voren dat vooral competenties zoals academische vaardigheden en innovatievermogen voorspellend zijn voor werk binnen het eigen kerndomein. Hoewel werkgevers ook aangeven deze competenties te waarderen, blijken zij een veel sterkere voorkeur te hebben voor sociale en commerciële vaardigheden. Deze vaardigheden lijken echter niet of nauwelijks samen te hangen met de kans dat afgestudeerden werk vinden binnen hun eigen kerndomein.

Dit verschil ligt vermoedelijk vooral aan een verschil in perspectief tussen afgestudeerden en werkgevers. In de HBO-Monitor is gekeken naar het effect van competenties op de kans op werk dat aansluit bij het niveau én de richting van de gevolgde HBO opleiding, terwijl bij het werkgeversonderzoek een dergelijke goede aansluiting als een gegeven wordt beschouwd bij de verdere beoordeling van de competenties van de kandidaten voor een baan. Waarschijnlijk worden sociale en commerciële vaardigheden niet alleen gewaardeerd door werkgevers die banen aanbieden die goed bij de HBO opleiding passen, maar ook door werkgevers die op zoek zijn naar iemand met een lager niveau en/of een andere richting. Dat zou verklaren waarom deze competenties niet differentiëren tussen werkenden binnen en werkenden buiten het eigen kerndomein. 
Hoe dan ook lijkt een goede mix aan competenties van groot belang te zijn. Het is moeilijk om een gebrek aan de ene competentie te compenseren door meer van een andere competentie. Over de hele linie zijn werkgevers op zoek naar afgestudeerden met een tamelijk evenwichtige combinatie van competenties. Dit wil overigens niet zeggen dat er geen plaats op de markt is voor accentverschillen of zelfs voor specialisten die alleen uitblinken op één of twee terreinen.

\section{Transparantie kan beter}

Werkgevers lijken nauwelijks onderscheid te maken tussen HBO-bachelors en HBO-ad programma's, of tussen WO-bachelors en WO-masters. Ad-programma's blijken erg weinig bekendheid te genieten onder werkgevers, en werkgevers die aangeven van zulke programma's wél te hebben gehoord, blijken geen duidelijk beeld te hebben van wat ze feitelijk inhouden. Ook excellentieprogramma's blijken nauwelijks bekend of gewaardeerd te zijn. Al met al zijn de meeste werkgevers weinig gericht op de bestaande differentie binnen het Nederlandse hoger onderwijs, behalve het onderscheid tussen $\mathrm{HBO}$ en WO, en daarbinnen tussen verschillende studierichtingen.

Deze situatie lijkt niet bevorderend te zijn voor een soepele transitie van het hoger onderwijs naar de arbeidsmarkt, of voor de aansluiting tussen de competenties die ze zoeken en de competenties waarover afgestudeerden beschikken. Dat wil niet zeggen dat de kennis en vaardigheden in bijvoorbeeld een HBO-ad programma, of in een excellentieprogramma op HBO- of WO-niveau, voor alle werkgevers niet interessant hoeven te zijn. Maar studiekiezers die overwegen een dergelijk programma te volgen, hebben een legitiem belang bij de vraag of er een reële vraag is naar deze kwalificaties op de arbeidsmarkt, al is dit alleen in de vorm van een niche-marktsegment. Als de overgrote meerderheid van werkgevers niet op de hoogte zijn van deze programma's, zullen afgestudeerden zich ná hun entrée op de arbeidsmarkt nog moeten bewijzen, met alle risico's van dien.

\section{"Lemons" vermijden}

Voor bijna alle kenmerken - zowel cv kenmerken als competenties - geldt dat werkgevers een veel groter onderscheid maken tussen mensen die laag scoren en mensen met een gemiddelde score, dan tussen een gemiddelde score en een hoge score. De implicatie is duidelijk: werkgevers zijn meer gericht op het weren van sollicitanten die onder de maat zijn (in de economische literatuur "lemons" genoemd), dan op het aantrekken van excellente werknemers. Dit is consistent met de economische wet van de afnemende meeropbrengsten: voorbij een bepaald punt moet steeds meer van een bepaalde productiefactor worden toegevoegd on eenzelfde stijging van de productie te realiseren. Als een werkgever bijvoorbeeld kan kiezen tussen een aantal kandidaten die allemaal een gemiddeld eindcijfer van 7 of meer hebben, zal hij/zij eerder kiezen voor een kandidaat met een eindcijfer van precies 7 met een half jaar relevante werkervaring, dan voor een kandidaat met een eindcijfer van 8 maar geen werkervaring. lets vergelijkbaar geldt ook voor competenties: werkgevers zullen eerder de voorkeur geven aan een afgestudeerde met een gemiddeld niveau van vakkennis én academische vaardig- 
heden, boven een afgestudeerde die uitblinkt in termen van academische vaardigeden maar onder de maat is in termen van vakkennis.

Dit is ook te begrijpen in termen van de schade die een werknemer zou kunnen aanrichten wanneer die ernstig tekort schiet op een bepaalde kwalificatie of competentie. Zo kan een afgestudeerde met een hoog eindcijfer erg slim zijn, maar als die geen werkervaring heeft is nog niet bewezen dat die in staat is om deze intelligentie om te zetten in productieve arbeid. 



\section{1 \\ INLEIDING}

In recente jaren is er veel aandacht voor de vraag wat werkgevers zoeken wanneer ze hoger opgeleiden in dienst nemen. Willen ze vooral specialisten met een hoge mate van expertise binnen het werkdomein waarbinnen ze worden ingezet, of zoekt men eerder allrounders die breed inzetbaar zijn? Hebben ze altijd een voorkeur voor kandidaten met de hoogste kwalificaties, of vinden ze dat werknemers soms te hoog gekwalificeerd kunnen zijn voor bepaalde functies? Zoeken ze de slimste jongens en meisjes van de klas - dat wil zeggen de afgestudeerden met de hoogste cijfers - of is een goede middenmoter ook geschikt? Hoe belangrijk is het dat men over werkervaring beschikt, en hoeveel is dan nodig? Hoe zit het met ervaring in het buitenland, of andere additionele ervaringen en kwalificaties die men tijdens een opleiding in het hoger onderwijs kan hebben opgedaan? En tenslotte, welke competenties zoeken werkgevers vooral?

Deze vragen worden nog belangrijker wanneer we ze tegen de achtergrond plaats van de grote veranderingen van de laatste jaren in termen van de inrichting van de economie en samenleving. Zoals Allen en Van der Velden (2011) duidelijk maken, worden veel van deze veranderingen gedreven en/of versterkt door ontwikkelingen in informatie- en communicatietechnologie. De veranderende technologie heeft ingrijpende consequenties voor de manier waarop mensen handelen op het werk, in het onderwijs, en in hun dagelijks leven. Het heeft ook een versterkend effect gehad op zaken zoals globalisering, flexibilisering van het werk en de polarisatie van de banenstructuur. Men wordt geacht om te kunnen communiceren en soms te concurreren met mensen in andere landen, zich op korte en langere termijn aan te passen aan snel veranderende eisen, en om rekening te houden met grote verschuivingen in de werkgelegenheid, waarbij er een toenemende behoefte is aan hooggekwalificeerde arbeidskrachten, en blijvende behoefte aan laaggeschoolde werknemers voor eenvoudig werk dat moeilijk te automatiseren is, maar waarbij een zekere uitholling waar te nemen is op het middelbaar niveau dat deels of zelfs geheel over te nemen is door machines en computers. Vanwege de vergrijzing valt een onevenredige last op de schouders van jonge mensen die recent de arbeidsmarkt zijn ingestroomd om deze problemen en uitdagingen het hoofd te bieden.

Hoewel zulke veranderingen duidelijk waarneembaar zijn, is het niet meteen duidelijk wat de implicaties zijn voor het soort kennis en vaardigheden waarover een hoger 
opgeleide heden ten dage dient te beschikken. Er is een zekere neiging ontstaan om automatisch aan te nemen dat nieuwe uitdagingen per se tot een nieuwe set competenties moet leiden, de zogenaamde "21st century skills" die men in staat zou stellen om in de complexe en snel veranderende wereld te functioneren. Het is echter de vraag in hoeverre dit echt het geval is. In een complexe wereld zijn immers concrete en specifieke kennis en vaardigheden nog belangrijker dan ooit, omdat het onmogelijk is de complexiteit te lijf te gaan gewapend met slechts goede algemene competenties. Sociale vaardigheden, flexibiliteit, ondernemerschap, en andere generieke competenties zijn ontegenzeggelijk ook belangrijk, maar zijn van beperkt nut tenzij toegepast in combinatie met een gedegen basis in termen van specifieke kennis en vaardigheden. Bovendien zijn zulke competenties altijd belangrijk geweest, ook in de 200 eeuw en vermoedelijk zelfs daarvoor. Het zou wel eens kunnen zijn dat er minder veranderingen zijn in termen van de benodigde competenties dan in de manier waarop men deze competenties toepast.

We beschikken al lange tijd in de vorm van de HBO-Monitor over interessante gegevens die licht kunnen werpen op de vraag wat werkgevers willen van HBO'ers in het Nederland van vandaag. Hoewel we zeer bewust zijn van de beperkingen van het gebruik van zelf-gerapporteerde antwoorden van afgestudeerden om een beeld te krijgen van de voorkeuren van hun werkgevers, zijn we van mening dat er een aantal grote voordelen zijn, mits de resultaten met zorg worden geïnterpreteerd. Het grootste voordeel schuilt in de rijkheid van de gegevens. In een typisch geval bevat een werkgeversonderzoek enkele tientallen tot enkele honderden respondenten, die namens een hele bedrijf, organisatie of afdeling antwoorden geven over het gevoerde beleid ten opzichte van hoe hoog opgeleiden worden gerekruteerd en/of ingezet. De HBO-Monitor daarentegen bevat gegevens van tienduizenden afgestudeerden op jaarbasis, die vanwege de hoge dekkingsgraad van het onderzoek een representatief beeld geeft van de arbeidsmarktintrede van alle nieuwe afgestudeerden van het HBO. Dit stelt ons in staat om niet alleen een betrouwbaar beeld te krijgen van de gemiddelde zelf-gerapporteerde werksituatie van afgestudeerden, maar ook om in detail naar verschillen te zoeken tussen verschillende groepen of categorieën afgestudeerden.

Een tweede voordeel is dat afgestudeerden per definitie een directe blik hebben op hun eigen werksituatie. Dit is in zekere zin de keerzijde van het belangrijkste nadeel van het gebruik van dergelijke gegevens - dat ze geen direct zicht hebben op de drijfveren en overwegingen van hun werkgevers. Dit voordeel is niet te verwaarlozen. Respondenten van werkgeversonderzoeken hebben vaak een zeer goed beeld van wat het bedrijf of de organisatie verwacht van hun hoog opgeleide werknemers in het algemeen, maar minder zicht op hoe deze mensen feitelijk worden ingezet op de werkvloer van dag tot dag. Vooral in combinatie met de bovengenoemde rijkheid van de gegevens kan dit grote voordelen opleveren, als aanvulling op het beeld dat van de werkgevers zelf afkomstig is. 
Zoals gezegd is belangrijk om hierbij altijd in gedachten te houden dat het hier om indrukken van werknemers gaat, en dat we dit derhalve hooguit als indirecte indicatie kunnen beschouwen van wat werkgevers feitelijk willen. Dit geldt zowel voor vragen in de monitor waarin direct wordt gevraagd naar werkgeversvoorkeuren - vereist opleidingsniveau, vereiste opleidingsrichting en vereist niveau van competenties als kenmerken van afgestudeerden waarvan aannemelijk is dat ze een rol spelen bij de selectie en allocatie door werkgevers - studierichting, cijfers, relevante ervaringen, andere kenmerken van de opleiding, e.d.

In dit rapport wordt gekeken naar hoe al deze kenmerken verschillen tussen afgestudeerden die qua huidige werksituatie van elkaar verschillen. Het gaat hierbij in eerste instantie om de aansluiting naar niveau en richting (waaraan in sommige gevallen de categorie "werkloos" wordt toegevoegd). Door de kenmerken tussen deze categorieën te vergelijken, wordt een beeld geschetst van wat kenmerkend is voor afgestudeerden die als volwaardige HBO'ers worden ingezet. Het is aannemelijk dat kenmerken die veel uitmaken voor de kans dat men binnen hun eigen kerndomein werkzaam is - dat wil zeggen, in een baan werken waarvoor minimaal HBO-niveau én de eigen of een verwante opleidingsrichting door de werkgever werd vereist - in het algemeen een sterkere rol hebben gespeeld bij de selectie dan kenmerken die hiervoor weinig uitmaken.

De HBO-Monitor data stellen ons in staat om nog een stap verder te gaan dan het vinden van kenmerken die belangrijk zijn in het algemeen. We kunnen ook kijken naar verschillen in het belang van deze kenmerken tussen verschillende categorieën werkgevers of banen. Hierbij kan worden gedacht aan verschillen naar organisatiegrootte, bedrijfssector en beroepsgroep, specifiek voor werkende binnen hun kerndomein.

Zoals gezegd is het perspectief van afgestudeerden interessant, maar hooguit als indirecte indicatie te beschouwen van wat werkgevers feitelijk willen. Als aanvulling hierop presenteren we derhalve in dit rapport ook het perspectief van werknemers. Begin 2014 is door het ROA eenmalig een vignettenanalyse uitgevoerd onder ruim 500 werkgevers, in het kader van de jaarlijkse HBO Monitor. Deze studie richt zich op het verzamelen van informatie omtrent de arbeidsmarktintrede van hbo afgestudeerden, maar dan vanuit het perspectief van (potentiele) werkgevers. Er wordt gekeken welke informatie werkgevers gebruiken wanneer zij 1) een sollicitant uitnodigen voor gesprek en 2) een sollicitant aannemen als werknemer. Het onderzoek richt zich specifiek op de voorkeuren van werkgevers die nieuwe afgestudeerden van het hoger onderwijs rekruteren voor hen bedrijf of organisatie. Een van de attributen waarnaar is gevraagd is of de betreffende opleiding een honours- of excellentieprogramma kent. De uitkomsten van deze studie bieden derhalve interessante informatie wat betreft de betekenis van deze programma's voor werkgevers.

In het volgende hoofdstuk wordt eerst ingegaan op de resultaten uit de HBO-Monitor. Om te beginnen kijken we naar het effect van verschillende kenmerken op de kans op werk binnen het eigen kerndomein. Daarna wordt gekeken naar het effect op respectie- 
velijk bedrijfsgrootte, beroepsrichting en bedrijfssector. Vervolgens worden de belangrijkste resultaten van het werkgeversonderzoek beschreven. 


\section{2 \\ UITKOMSTEN VAN DE HBO-MONITOR}

\subsection{Kans op werk in kerndomein}

In deze paragraaf wordt gekeken naar de kans dat afgestudeerden met verschillende onderwijsresultaten en -ervaringen in banen terechtkomen in hun eigen kerndomein, dan wel onder hun niveau en/of buiten hun richting werken, of helemaal geen werk hebben. We kijken hierbij naar de HBO-sector, de opgedane competenties, het gemiddelde eindcijfer, verschillende soorten ervaringen die men zou kunnen hebben opgedaan tijdens de HBO-opleiding, en hun oordelen achteraf over hun opleiding. Deze kenmerken worden als onafhankelijke of verklarende variabelen behandeld, en de kans dat men werk op of onder het eigen niveau dan wel buiten de eigen richting als uitkomst. We willen hierbij niet suggereren dat de resultaten van deze analyses zonder meer als causaal dienen te worden geïnterpreteerd, enkel dat afgestudeerden met een bepaalde score op deze kenmerken met verschillende waarschijnlijkheid een bepaalde arbeidsmarktsituatie kennen.

We kijken eerst naar een aantal bivariate relaties, omdat dit een scherper beeld geeft van de aard van deze relaties dan we kunnen geven met een multivariate benadering. Omdat veel van deze relaties met elkaar, of met andere kenmerken, verstrengeld zouden kunnen zijn, kijken we vervolgens naar multivariate relaties. Alle analyses hebben betrekking op afgestudeerden van voltijd HBO-opleidingen die in de uitvoeringsjaren 2008-2012 benaderd zijn en die op het moment van de enquête 36 jaar of jonger waren en tot de beroepsbevolking behoorden. In zowel de bivariate als de multivariate analyses wordt de groep afgestudeerden met "passend werk" - dat wil zeggen een baan waarvoor minimaal HBO-niveau en de eigen of een verwante richting werd vereist - als referentiecategorie gehanteerd, en wordt gefocust op de relatie tussen de genoemde onderwijskenmerken en de kans dat men op het moment van de enquête onder HBO niveau en/of buiten de eigen richting werkzaam dan wel werkloos was.

\section{De relatie met $\mathrm{HBO}$-sector}

Figuur 1 toont de relatie tussen de HBO-sector van afgestudeerden en de kans dat men buiten het eigen kerndomein terechtkomt, uitgesplitst in werk dat buiten de eigen richting (maar nog altijd op minimaal HBO-niveau) is, werk dat onder HBO-niveau (maar nog altijd binnen de eigen of een verwante richting) is, werk dat zowel buiten de eigen 
richting als onder HBO-niveau is, en werkloosheid. Afgestudeerden die zich niet hebben aangeboden op de arbeidsmarkt zijn buiten beschouwing gelaten, omdat er per definitie geen selectie door werkgevers op deze mensen heeft kunnen plaatsvinden. ' De "ruimte" tussen de bovenste van de gestapelde vlakken en $100 \%$ is het deel van de afgestudeerden dat binnen het eigen kerndomein werkt.

FIGUUR 1 Kans dat men buiten het eigen kerndomein terechtkomt, naar HBO-sector, 2008-2012 (gepoolde data)

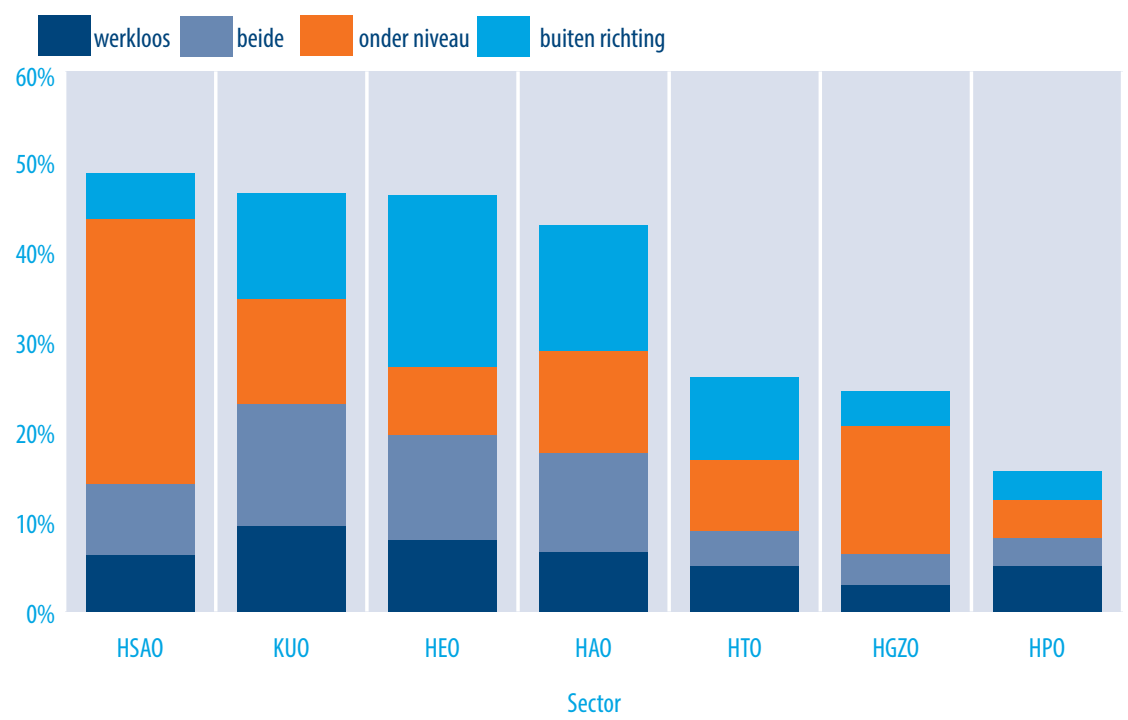

$\mathrm{N}=55.897$

Hoewel het enigszins geforceerd is om dit uit te leggen in termen van werkgeversvoorkeuren, is duidelijk dat er grote verschillen zijn tussen $\mathrm{HBO}$ opleidingssectoren in termen van kansen op werk binnen het eigen kerndomein. Bijna de helft van de afgestudeerden van de sectoren HSAO, KUO en HEO die zich op de arbeidsmarkt aanbieden komt buiten het eigen kerndomein terecht. Dit geldt voor slechts ongeveer een kwart van de HTO'ers en HGZO'ers, en iets meer dan één op de zes HPO'ers.

Er zijn ook grote verschillen in de precieze bestemming van afgestudeerden die buiten hun kerndomein terechtkomen. Bijna een derde van alle HSAO'ers komt in een baan terecht waarvoor een lager opleidingsniveau werd vereist, maar nog altijd in de eigen of een verwante richting. Hoewel in absolute termen de percentages veel lager zijn, is een soortgelijk patroon zichtbaar onder HGZO'ers die buiten hun kerndomein terecht-

$1 \quad$ Strikt gesproken hoeft dit niet het geval te zijn. Het bekende "discouraged worker" effect (Akyeampong 1992) gaat ervan uit dat sommige mensen na verloop van tijd ontmoedigd raken door het feit dat ze geen werk hebben kunnen vinden, en zich helemaal terugtrekken uit de arbeidsmarkt. Omdat we geen mogelijkheid hebben om deze mensen te onderscheiden van mensen die om andere redenen zich niet hebben aangeboden, laten we deze hele categorie buiten beschouwing. 
komen. Dit ligt heel anders voor afgestudeerden van de sectoren HEO, HAO, die relatief vaak buiten de eigen richting werkzaam zijn, hetzij op HBO niveau, hetzij op een lager niveau.

\section{De relatie met competenties}

In het geval van competenties hebben we twee mogelijkheden. We kunnen de relatie zien met het eigen niveau van competenties, of de relatie met het niveau dat door werkgevers wordt vereist. Hoewel het beter in de logica van dit rapport als geheel zou hebben gepast om het eigen niveau te gebruiken, komt het vereiste niveau naar onze mening dichter in de buurt van feitelijke voorkeuren van werkgevers. Figuur 2 toont de relatie tussen het vereiste niveau van een aantal geselecteerde competenties en de kans dat men buiten het eigen kerndomein terechtkomt.

Figuur 2 laat zien dat deze relatie heel verschillend is voor verschillende competenties. Niet geheel verassend, de relatie tussen kennis van het eigen vakgebied en de kans op werk in het eigen kerndomein is heel sterk. In bijna 90\% van de banen waar een matig niveau van deze competentie werd vereist, gaat het om werk buiten het eigen kerndomein. Meer dan de helft van deze afgestudeerden werkt zelfs geheel buiten het eigen kerndomein. Deze percentages zakken naar slechts $20 \%$ en $3 \%$ bij een uitmuntend vereist niveau.

Het vermogen om logisch te redeneren hangt eveneens sterk samen met de kans op werk buiten het kerndomein. In dit geval is het vooral de kans op werk op minimaal HBO niveau dat hiermee samenhangt. Er is nauwelijks een relatie tussen het vereist niveau van deze competentie en de kans op werk op eigen niveau maar buiten de eigen richting. Datzelfde geldt voor de overige competenties: het vermogen om nieuwe ideeën en oplossingen te bedenken, om capaciteiten van anderen aan te spreken, om productief met anderen samen te werken en om conform budgetten, richtlijnen e.d. te werken. Het niveau van deze meer generieke competenties lijkt dus vooral met het vereist opleidingsniveau samen te hangen. Alleen de specifieke competentie kennis van het eigen vakgebied hangt ook sterk samen met de vereiste opleidingsrichting. 
FIGUUR 2 Kans dat men buiten het eigen kerndomein terechtkomt, naar vereist niveau van geselecteerde competenties

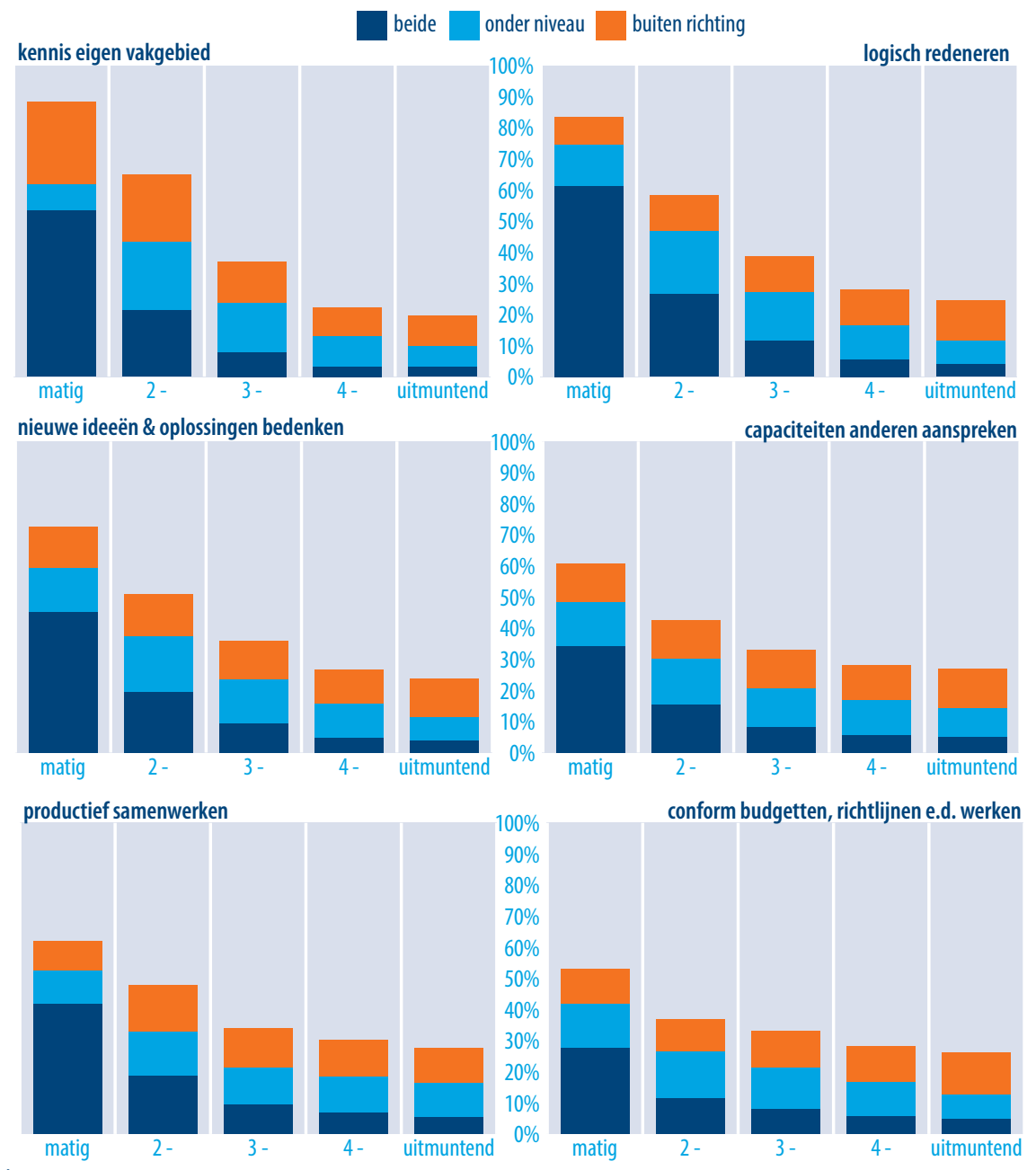

$\mathrm{N}=45.223$

\section{De relatie met eindcijfer}

We kijken nu naar de relatie tussen het gemiddelde eindcijfer in de $\mathrm{HBO}$-opleiding en de kans dat men wel of geen werk vindt binnen het eigen kerndomein. In hoeverre vinden we ondersteuning voor de stelling dat werkgevers hierop selecteren? Figuur 3 toont deze relatie. 
FIGUUR 3 Kans dat men buiten het eigen kerndomein terechtkomt, naar gemiddeld eindcijfer

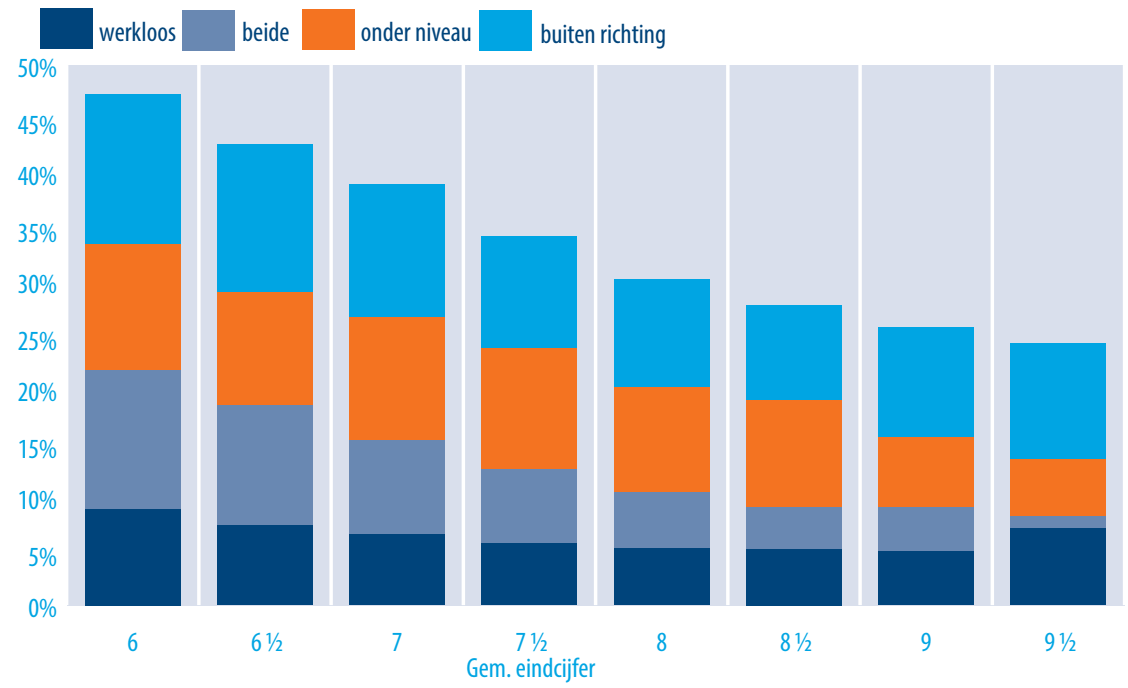

$\mathrm{N}=47.729$

Er is een tamelijk sterke relatie tussen het gemiddelde eindcijfer en de kans op werk binnen het eigen kerndomein, hoewel iets minder sterk dan de waargenomen relatie met de meeste competenties. Als we alle categorieën bij elkaar bekijken neemt de kans op werk buiten de eigen kerndomein min of meer lineair af met toenemende cijfers. Nader inspectie van de percentages laat zien dat deze relatie vrijwel in het geheel wordt gedreven door het effect op de kans op werk onder het eigen niveau, al of niet in combinatie met werken buiten de eigen richting. Cijfers hebben nagenoeg geen enkel effect op de kans om alleen buiten de eigen richting te werken. Interessant is de bevinding dat het gemiddelde eindcijfer ook geen noemenswaardig effect lijkt de hebben op de kans op werkloosheid.

\section{De relatie met selectiviteit/moeilijkheid van de opleiding}

In de vragenlijst van de HBO-Monitor is een aantal vragen opgenomen die gericht zijn op het vaststellen van de mate van selectiviteit van de opleiding. Hoewel dit niet iets is waarop werkgevers direct kunnen selecteren - we mogen aannemen dat ze in het algemeen weinig zicht hebben op zulke aspecten van de opleiding - is het denkbaar dat afgestudeerden van selectieve opleidingen de vruchten plukken van het volgen van selectieve opleidingen, hetzij direct door de competenties die ze hierdoor hebben opgedaan, hetzij indirect door het feit dat selectieve opleidingen in de loop van de tijd een betere reputatie krijgen bij werkgevers. Één van deze vragen had betrekking op de vraag in hoeverre men de opleiding uitdagend vond qua niveau. Figuur 4 toont de relatie tussen dit oordeel van afgestudeerden en de kans dat men wel of geen werk vindt binnen het eigen kerndomein. 
FIGUUR 4 Kans dat men buiten het eigen kerndomein terechtkomt, naar oordeel over de mate waarin de gevolgde opleiding uitdagend was qua niveau

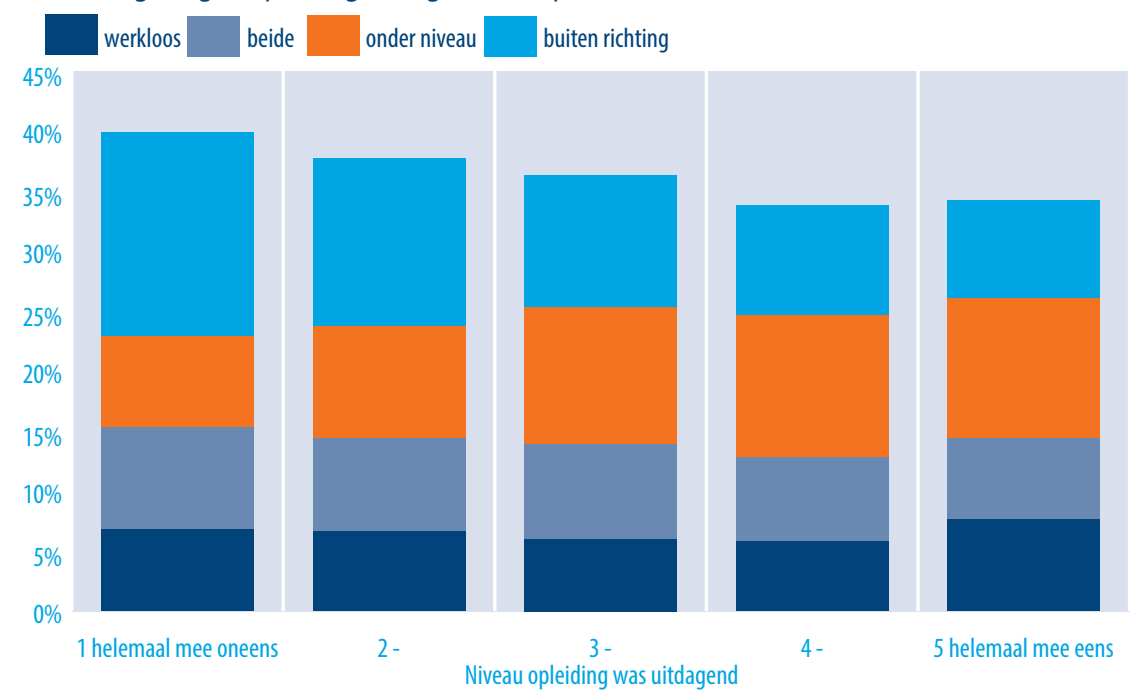

$\mathrm{N}=51.574$

Deze relatie is verassend zwak, en is vrijwel in het geheel gebaseerd op de verlaagde kans op werk op HBO-niveau buiten de eigen of een verwante richting. De kans op werk onder HBO-niveau binnen de eigen of verwante richting wordt juist groter naarmate men meer instemt met dit oordeel. Hierbij moet worden opgemerkt dat dit een individueel oordeel is, dat beïnvloed kan zijn zowel door de feitelijke aard van de opleiding als door de capaciteiten van de afgestudeerde. In de multivariate analyses wordt een schaal gebruikt op basis van zes items, en dit wordt gesplitst in een opleidingsgemiddelde en een individuele afwijking. ${ }^{2}$

\section{De relatie met ervaringen tijdens de opleiding}

Er wordt vaak verondersteld dat werkgevers sterk gericht zijn op ervaringen die men tijdens de $\mathrm{HBO}$-opleiding hebben opgedaan. Men kan relevante werkervaring hebben opgedaan, of bestuurlijke ervaring in bijvoorbeeld een student- of sportvereniging, of hebben gewerkt of een deel van hun studie hebben gevolgd in het buitenland. Zien we indicaties dat werkgevers sterker op zulke ervaringen selecteren voor functies binnen het eigen kerndomein dan voor functies daarbuiten? Figuur 5 toont de relatie tussen verschillende soorten ervaring tijdens de opleiding en de kans dat men wel of geen werk vindt binnen het eigen kerndomein.

2 De bivariate relatie is grotendeels hetzelfde voor alle zes schaal items. 
FIGUUR 5 Kans dat men buiten het eigen kerndomein terechtkomt, naar ervaring tijdens de opleiding

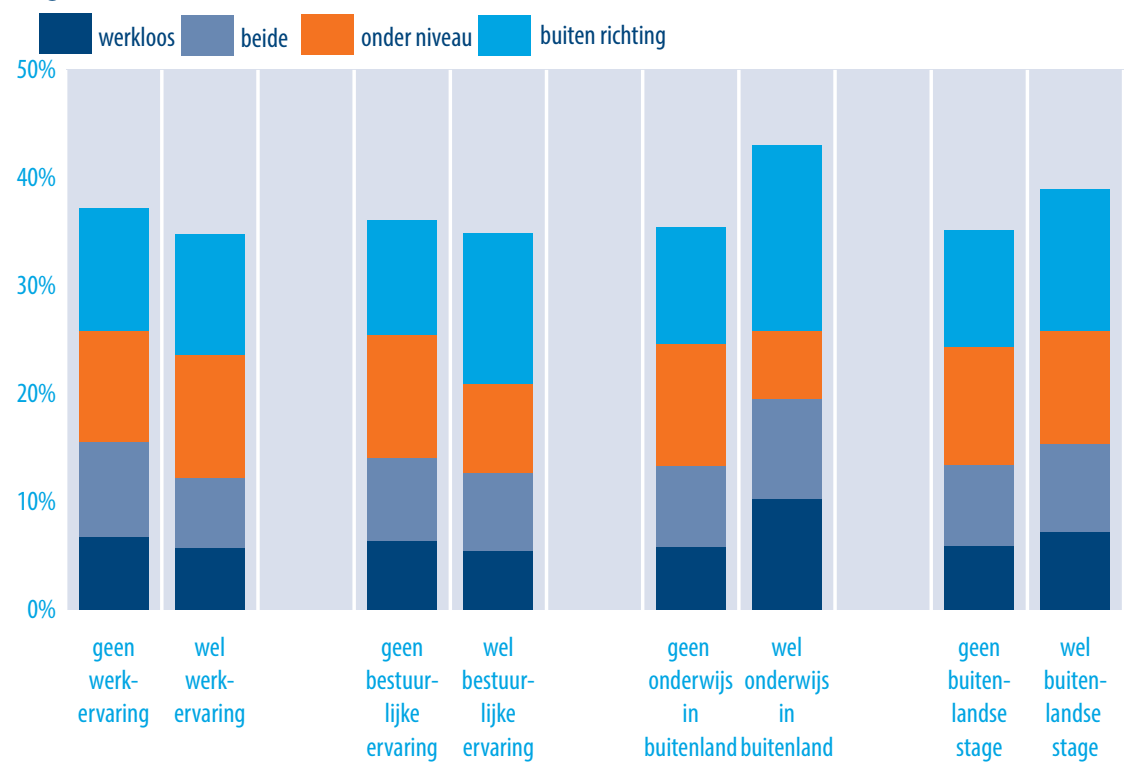

$\mathrm{N}=52.324$

Het effect van ervaringen tijdens de opleiding is verassend zwak. Wel zien we effecten in de verwachte richting voor relevante werkervaring en bestuurlijke ervaring. In het geval van buitenlandervaring is het effect zelfs negatief. Dit laatste effect illustreert het feit dat we voorzichtig moeten zijn in het toekennen van causaliteit aan deze relaties. Hoewel het denkbaar is dat werkgevers niet in buitenlandervaring van afgestudeerden geïnteresseerd zijn, lijkt niet aannemelijk dat ze een voorkeur hebben voor mensen zonder zulke ervaring. Waarschijnlijker is dat er andere kenmerken zijn die negatief samenhangen met buitenlandervaring, maar positief met de kans op werk binnen het eigen kerndomein (of andersom).

\section{Multivariate schattingen}

Om deze reden hebben wij een multinomiale regressie geschat, waarin het effect van een heel reeks kenmerken wordt geschat op de kans op werk buiten de eigen richting maar op eigen niveau, werk onder HBO-niveau maar buiten de eigen richting, of werk zowel buiten de richting als onder het eigen niveau werd geschat, relatief tot de kans op werk binnen het eigen kerndomein. Bij een dergelijke multivariate schatting worden alle effecten gecorrigeerd voor het effect van alle andere in de analyse opgenomen kenmerken. Uiteraard geeft dit geen garantie dat er geen andere, niet-waargenomen kenmerken zijn die de geschatte effecten niet deels zouden hebben veroorzaakt, maar het geeft een beter beeld dan wanneer we de zaak alleen bivariaat bekijken. 


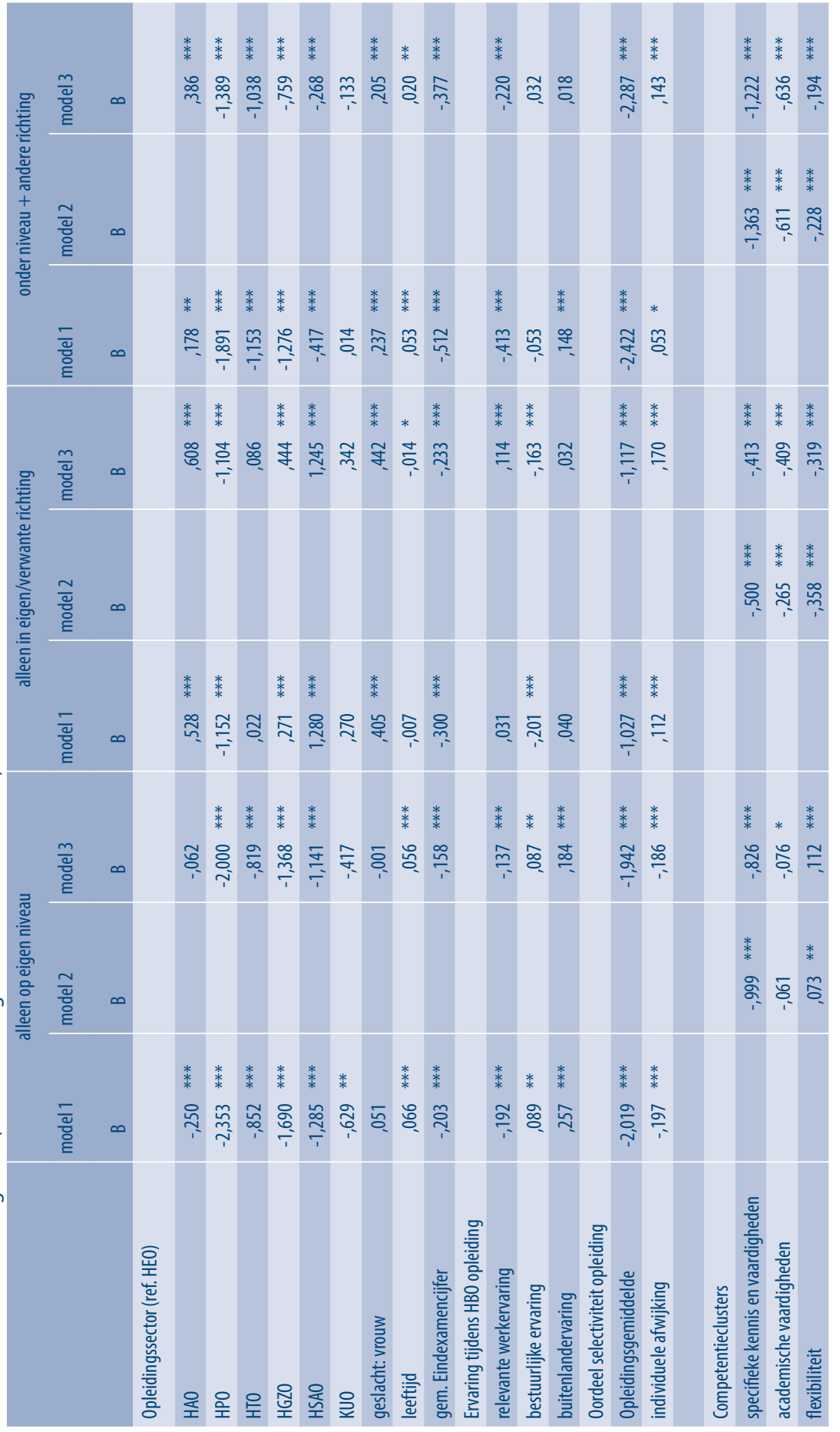




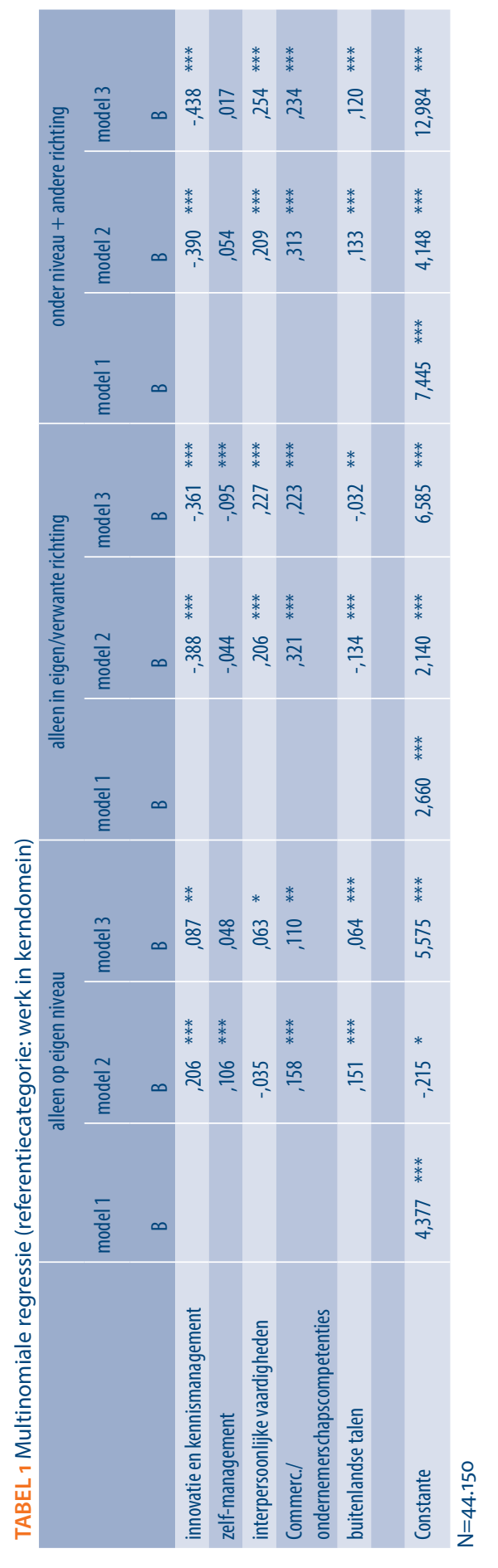


Tabel 1 toont de resultaten. Om beter zicht te geven op de effecten van respectievelijk vereiste competenties en andere kenmerken, worden drie modellen geschat: één met alleen opleidings- en persoonskenmerken (model 1), één met alleen competenties (model 2, en één met zowel competenties als andere kenmerken (model 3).

Om onnodige herhaling te vermijden, richten we ons in eerste instantie op de effecten waarin gecontroleerd wordt voor zowel competenties als andere kenmerken (model 3). Dit is immers het meest complete model, dat derhalve het beste schatting geeft van de "zuivere" effecten van alle kenmerken. Vervolgens gaan we na in hoeverre deze effecten anders zijn dan de effecten waarin niet wordt gecontroleerd (modellen 1 en 2).

We zien dat de verschillen tussen opleidingssectoren die we in figuur 1 zagen grotendeels overeind blijven in de multivariate analyse. Uit de vele negatieve coëfficiënten voor de overige sectoren blijkt dat afgestudeerden van de referentiesector HEO relatief vaak buiten de eigen richting werkzaam waren, hetzij op HBO niveau, hetzij daaronder, met als enige uitzondering dat afgestudeerden van het HAO iets vaker helemaal buiten het eigen kerndomein werkzaam waren. Op HPO na blijkt echter dat HEO'ers de laagste kans hadden om binnen de eigen richting op HBO werkzaam te zijn. HPO'ers blijken in alle opzichten de sector met de laagste kans op werk buiten het kerndomein. Net als HPO'ers bleken HSAO'ers en HGZO'er relatief zelden buiten de eigen richting te werken, maar anders dan HPO kwam het voor de afgestudeerden van deze sector relatief vaak voor dat ze onder hun niveau maar binnen de eigen of verwante richting werkten. Dit geeft de permeabiliteit van de grens tussen werk op MBO versus HBO niveau weer. $\mathrm{Er}$ is vooralsnog geen sprake van een vergelijkbare permeabiliteit in de onderwijssector.

Vrouwen werken even vaak als mannen buiten de eigen of verwante richting op HBO niveau, maar hebben een veel grotere kans om onder HBO niveau te werken. Bij oudere afgestudeerden is juist het risico op werk buiten de eigen richting groter dan bij jongere afgestudeerden. Goede eindcijfers lijken in alle opzichten sterk te differentiëren in termen van de kans op werk binnen of buiten het eigen kerndomein.

De effecten van verschillende soorten werkervaring tijdens de HBO-opleiding tonen een interessant patroon. Zoals zou worden verwacht verlaagt relevante werkervaring de kans op werk buiten de eigen opleidingsrichting, zowel op HBO-niveau als daaronder. Echter, zulke ervaring verhoogt de kans op werk onder het eigen niveau maar binnen de eigen of verwante richting. Dit laatste effect kan een gevolg zijn van het feit dat sommige afgestudeerden na afstuderen blijven werken in dezelfde baan als ze tijdens de opleiding hadden. Bij nader inspectie blijkt dat dit effect alleen significant wordt na controle voor vereiste competenties. We komen zo meteen hierop terug.

De zes vragen in de vragenlijst die betrekking hebben op de interne selectiviteit zijn samengevoegd tot een enkele schaal, waarbij de twee vragen die een omgekeerde formulering hebben eerst gehercodeerd zijn om in dezelfde richting te wijzen als de overige vier vragen. Omdat het de bedoeling is dat deze vraag iets zegt over de oplei- 
ding in plaats van over de persoon, is van deze schaal een opleidingsgemiddelde berekend. Naast dit gemiddelde is in de analyses ook een individuele afwijking berekend. Omdat het hierbij om individuen gaat die hun opleiding min of meer selectief vond dan hun studiegenoten, zou deze afwijking een additionele (negatieve) indicator zijn voor persoonlijke capaciteiten.

Zoals verwacht, heeft het opleidingsgemiddelde van de selectiviteitsschaal een sterk effect op de kans op werk binnen het kerndomein. Bewust of onbewust lijken werkgevers die banen aanbieden die zowel naar niveau als naar richting aansluiten bij de opleiding van de afgestudeerden, een sterke voorkeur te hebben voor afgestudeerden van selectievere opleidingen. Dit lijkt vooral te gelden voor de kans op werk binnen de eigen of verwante opleidingsrichting. De individuele afwijking heeft het verwachte versterkende effect op de kans op werk onder HBO-niveau, zowel binnen als buiten de eigen richting. Anders dan verwacht lijkt de individuele component een remmend effect te hebben op de kans dat men op HBO-niveau buiten de eigen richting werkzaam is.

Omdat het weinig zinvol is om alle 23 competenties los op te nemen, zijn deze met elkaar gecombineerd in een achttal clusters:

- Specifieke kennis en vaardigheden: kennis van eigen vakgebied, vermogen om vakkennis is de praktijk toe te passen;

- Academische vaardigheden: vermogen om logisch te redeneren, om hoofd van bijzaken te onderscheiden, om verbanden te leggen tussen verschillende zaken, en de bereidheid om ideeën van zichzelf en anderen ter discussie te stellen;

- flexibiliteit: kennis van andere vakgebieden, vermogen om nieuwe dingen te leren

- innovatie en kennismanagement: vermogen om nieuwe ideeën en oplossingen te bedenken, om informatie te vergaren, en om ICT te gebruiken;

- (zelf-)management vaardigheden: vermogen om conform budget, planning of richtlijnen te werken, om capaciteiten van anderen aan te spreken, en om zelfstandig de werkzaamheden uit te voeren;

- interpersoonlijke vaardigheden: vermogen om aan anderen duidelijk te maken wat men bedoelt, en om productief met anderen samen te werken;

- commerciële/ondernemerschapscompetenties: vermogen om problemen en kansen te signaleren, om onder druk te functioneren, om knopen door te hakken, de bereidheid de nek uit te steken en om op te komen voor het eigen standpunt;

- buitenlandse talen: vermogen om in buitenlandse talen te communiceren;

- niet ingedeeld: bereidheid om begrip te tonen voor andere standpunten.

De sterkste effecten zijn te zien voor specifieke kennis en vaardigheden en academische vaardigheden, vooral de eerstgenoemde. Beide van deze clusters hebben het sterkst remmend effect op werk geheel buiten het eigen kerndomein. Specifieke kennis en vaardigheden heeft daarnaast een sterk remmend effect op de kans op werk op HBO-niveau maar buiten de eigen of verwante richting, en een minder sterk effect op de kans op werk op een lager niveau maar binnen de eigen of verwante richting. Het omge- 
keerde geldt voor academische vaardigheden. Dit patroon is sterk in lijn met wat we zouden verwachten bij specifieke versus generieke vaardigheden, en wordt in minder sterke mate teruggevonden bij de generieke clusters flexibiliteit en innovatie en kennismanagement. (Zelf-)management en buitenlandse talen hebben slechts vrij zwakke effecten, die in het geval van talenkennis eerder positief dan negatief werken op de kans op werk buiten het eigen kerndomein. Nog sterkere positieve effecten zijn te zien in het geval van interpersoonlijke en commerciële/ondernemerschapscompetenties, vooral voor de kans op werk onder HBO-niveau (al of niet in combinatie met werk buiten de eigen richting). Dit suggereert dat er nog altijd niet waargenomen kenmerken in het spel zijn die deze effecten veroorzaken.

Wanneer we naar het verschil tussen de kolommen met en zonder controle kijken zien we dat een aanzienlijk deel van het effect van veel kenmerken wordt wegverklaard door de competentieclusters. Dit lijkt vooral te gelden voor de kans op werk buiten de eigen richting (zowel op als onder HBO-niveau), en minder voor de kans op werk onder $\mathrm{HBO}-n i v e a u$ binnen de eigen richting. Dit is consistent met de bevinding dat vakkennis het sterkste effect heeft, en dat dit cluster veel meer effect heeft op de richting dan op het niveau van de baan. Vooral de effecten van eindcijfer en ervaring tijdens de opleiding lijken vrij sterk via competenties te lopen. Interessant genoeg lijkt dit slechts in geringe mate te gelden voor het opleidingsgemiddelde van selectiviteit. Het positief effect van de individuele afwijking van selectiviteit op de kans op werk onder het eigen niveau (zowel binnen als buiten de eigen richting) wordt door de toevoeging van de competentieclusters zelfs versterkt.

Wat het effect van competenties betreft zien we een aantal interessante verschillen in termen van de veranderingen in coëfficiënten vóór en ná controle voor andere kenmerken. Over de hele linie worden de effecten - zowel positief als negatief - afgezwakt. Dit lijkt een indicatie te zijn dat een deel van het "effect" van deze competenties feitelijk een gevolg is van compositie effecten in termen van zaken als opleidingsrichting, cijfers, ervaring en persoonlijke kenmerken. Er zijn echter uitzonderingen. Zo wordt het effect van academische vaardigheden juist versterkt, vooral voor wat betreft het effect op de kans op werk onder niveau maar binnen de eigen of verwante richting. Ook wordt het positieve effect van interpersoonlijke vaardigheden versterkt.

\subsection{Verschillen naar baan- en bedrijfskenmerken}

De analyses boven geven een beeld van welke kenmerken in het algemeen het meest differentiëren tussen werk binnen of buiten het kerndomein. De uitkomsten kunnen als een indicatie worden gezien van de algemene voorkeuren van werkgevers in termen van dergelijke kenmerken. In de volgende paragrafen wordt voor afgestudeerden binnen het eigen kerndomein gekeken naar de relatie tussen deze kenmerken en de kans op werk in kleine of grote bedrijven (in vergelijking met werken in middelgrote bedrijven, en de kans op werk in verschillende beroependomeinen. Hierdoor kunnen 
we een beeld krijgen van de mate waarin de voorkeur voor deze kenmerken verschilt tussen werkgevers en banen.

Tabel 2 toont het effect van competenties en andere kenmerken op de kans dat men in een klein of groot bedrijf werkzaam is, ten opzichte van de kans op werk in een middelgroot bedrijf.

TABEL 2 Multinomiale regressie (referentiecategorie: 50-249 pers.)

\begin{tabular}{|c|c|c|c|c|}
\hline & \multicolumn{2}{|c|}{$\begin{array}{c}<50 \text { pers. } \\
\text { B }\end{array}$} & \multicolumn{2}{|c|}{$\begin{array}{c}>=250 \text { pers. } \\
\text { B }\end{array}$} \\
\hline Constante & 3,921 & $* * *$ & $-1,589$ & $* * *$ \\
\hline \multicolumn{5}{|l|}{ Opleidingssector (ref. HEO) } \\
\hline HAO &, 322 & $* * *$ &,- 350 & *** \\
\hline HPO & ,163 & $* * *$ & $-1,108$ & $* * *$ \\
\hline НTO & ,266 & $* * *$ &,- 147 & $* * *$ \\
\hline HGZO & 1,702 & $* * *$ & ,781 & $* * *$ \\
\hline HSAO &,- 652 & $* * *$ & 211 & $* * *$ \\
\hline KUO &, 868 & $* * *$ &,- 849 & $* * *$ \\
\hline geslacht: vrouw &, 033 & &, 093 & $* *$ \\
\hline leeftijd &,- 017 & $* *$ &, 004 & \\
\hline gem. eindexamencijfer &, 040 & &, 064 & $* *$ \\
\hline \multicolumn{5}{|l|}{ Ervaring tijdens $\mathrm{HBO}$ opleiding } \\
\hline relevante werkervaring &, 007 & &,- 018 & \\
\hline bestuurlijke ervaring &, 076 & * & ,107 & $* * *$ \\
\hline buitenlandervaring &, 012 & &, 016 & \\
\hline \multicolumn{5}{|l|}{ Oordeel selectiviteit opleiding } \\
\hline Opleidingsgemiddelde & $-1,457$ & $* * *$ & ,369 & $* * *$ \\
\hline individuele afwijking &, 010 & &, 009 & \\
\hline \multicolumn{5}{|l|}{ Competentieclusters } \\
\hline specifieke kennis en vaardigheden &, 114 & *** &,- 101 & *** \\
\hline academische vaardigheden &,- 006 & & 169 & *** \\
\hline flexibiliteit &, 168 & $* * *$ &, 094 & *** \\
\hline innovatie en kennismanagement &, 084 & ** &,- 064 & * \\
\hline zelf-management & 092 & ** &,- 038 & \\
\hline interpersoonlijke vaardigheden &,- 310 & $* * *$ & ,136 & $* * *$ \\
\hline Commerc./ondernemerschapscompetenties &, 010 & &,- 069 & \\
\hline buitenlandse talen &,- 014 & &, 029 & ** \\
\hline
\end{tabular}

$\mathrm{N}=30.127$

Afgestudeerden van de sector HSAO werken vaker in grote bedrijven en minder in kleine bedrijven. Afgestudeerden van de sector HGZO werken vaker in zowel grote als kleine bedrijven. Afgestudeerden van de overige sectoren werken vaker in kleine bedrijven en minder vaak in grote bedrijven. Dit alles wordt bezien relatief tot de sector HEO. Deze 
effecten weerspiegelen vooral de verschillen in de typische organisaties waarbinnen afgestudeerden werken.

Vrouwen werken iets vaker in groter bedrijven, oudere afgestudeerden iets minder vaak in kleine bedrijven. Cijfers, bestuurlijke ervaring en selectiviteit (het opleidingsgemiddelde) verhogen enigszins de kans op werk in een groot bedrijf. Selectiviteit verlaagt tevens sterk de kans op werk in een klein bedrijf. Wat competenties betreft zien we uiteenlopende effecten: specifieke kennis en vaardigheden, innovatie en kennismanagement en in mindere mate zelf-management hangen negatief samen met bedrijfsgrootte; interpersoonlijke vaardigheden en in mindere mate academische vaardigheden en buitenlandse talen hangen er positief mee samen. Flexibiliteit versterkt de kans dat men in zowel grote als kleine bedrijven werkt.

TABEL 3 Multinomiale regressie (referentiecategorie: Economische/administratieve beroepen)

\begin{tabular}{|c|c|c|c|c|c|c|}
\hline & \multicolumn{2}{|c|}{$\begin{array}{c}\text { Natuur/techniek } \\
\text { B }\end{array}$} & \multicolumn{2}{|c|}{$\begin{array}{c}\text { Sociaal, cultureel en } \\
\text { onderwijsberoepen } \\
\text { B }\end{array}$} & \multicolumn{2}{|c|}{$\begin{array}{c}\text { Verzorgend/medisch } \\
\text { B }\end{array}$} \\
\hline Constante & $-3,972$ & $* * *$ & $-19,632$ & $* * *$ & 5,959 & $* * *$ \\
\hline \multicolumn{7}{|l|}{ Opleidingssector (ref. HEO) } \\
\hline $\mathrm{HAO}$ & 3,239 & $* * *$ &, 074 & & 1,207 & $* * *$ \\
\hline HPO & 2,183 & $* * *$ & 3,399 & $* * *$ & 6,937 & $* * *$ \\
\hline HTO & 3,525 & $* * *$ & 2,159 & $* * *$ &, 448 & $* * *$ \\
\hline HGZO & 1,314 & $* * *$ & 7,410 & $* * *$ & 2,390 & $* * *$ \\
\hline HSAO &,- 152 & & 4,326 & $* * *$ & 3,933 & $* * *$ \\
\hline KUO & 1,840 & $* * *$ & $-21,897$ & $* * *$ & 4,257 & $* * *$ \\
\hline geslacht: vrouw &,- 459 & $* * *$ & 1,422 & $* * *$ &, 772 & $* * *$ \\
\hline leeftijd &,- 026 & $* *$ &,- 027 & &, 038 & $* * *$ \\
\hline gem. eindexamencijfer &, 034 & & 124 & $* *$ & 155 & $* * *$ \\
\hline \multicolumn{7}{|l|}{ Ervaring tijdens $\mathrm{HBO}$ opleiding } \\
\hline relevante werkervaring &,- 256 & $* * *$ &,- 033 & &, 049 & \\
\hline bestuurlijke ervaring &, 052 & &,- 246 & ** &,- 130 & $* *$ \\
\hline buitenlandervaring &, 073 & &, 315 & $* * *$ &,- 138 & ** \\
\hline \multicolumn{7}{|l|}{ Oordeel selectiviteit opleiding } \\
\hline Opleidingsgemiddelde &, 736 & $* * *$ & 4,709 & $* * *$ & $-3,848$ & $* * *$ \\
\hline individuele afwijking &, 009 & &, 052 & &, 040 & \\
\hline \multicolumn{7}{|l|}{ Competentieclusters } \\
\hline specifieke kennis en vaardigheden &, 166 & $* * *$ &, 476 & $* * *$ &, 125 & $* * *$ \\
\hline academische vaardigheden &,- 010 & &,- 225 & ** &,- 142 & ** \\
\hline flexibiliteit &,- 028 & &,- 327 & $* * *$ &,- 139 & $* * *$ \\
\hline innovatie en kennismanagement &,- 267 & $* * *$ &,- 489 & $* * *$ &,- 076 & \\
\hline zelf-management &, 037 & &, 036 & &,- 107 & $* *$ \\
\hline interpersoonlijke vaardigheden &, 080 & &, 342 & $* * *$ &, 282 & *** \\
\hline Commerc./ondernemerschapscompetenties &, 031 & &, 048 & &, 118 & * \\
\hline buitenlandse talen &,- 058 & $* * *$ &,- 055 & * &,- 223 & $* * *$ \\
\hline
\end{tabular}

$\mathrm{N}=30.044$ 
Tabel 3 toont het effect van competenties en andere kenmerken op de kans dat men in verschillende beroepsrichtingen werkzaam is, ten opzichte van de kans op werk in een economische/administratief beroep.

Weinig verassend werken afgestudeerden van de referentiecategorie het vaakst in economische/administratieve beroepen, waardoor vrijwel alle coëfficiënten voor de overige sectoren in de andere richtingen positief zijn. Uitzondering is de erg kleine kans dat KUO'ers in een sociaal, cultureel of onderwijsberoep werkt.

TABEL 4 Multinomiale regressie (referentiecategorie: Landbouw, industrie, energie en bouw)

\begin{tabular}{|c|c|c|c|c|c|c|c|c|}
\hline & $\begin{array}{r}\text { Financiele, Z } \\
\text { en comme } \\
\text { dienstverle } \\
\text { B }\end{array}$ & $\begin{array}{l}\text { zakelijk } \\
\text { arciele } \\
\text { ening }\end{array}$ & $\begin{array}{c}\text { Openbaar b } \\
\text { B }\end{array}$ & estuur & $\begin{array}{c}\text { Zorg \& We } \\
\text { B }\end{array}$ & & $\begin{array}{c}\text { Onderv } \\
\text { B }\end{array}$ & \\
\hline Constante & 2.792 & $* * *$ & -.731 & & -9.349 & $* * *$ & -6.083 & *** \\
\hline Opleidingssector (ref. HEO) & & & & & & & & \\
\hline HAO & -1.361 & $* * *$ & -.854 & $* * *$ & -1.030 & $* * *$ & -.124 & \\
\hline HPO & .406 & ** & .953 & $* * *$ & 2.877 & *** & 5.967 & $* * *$ \\
\hline HTO & -1.236 & $* * *$ & -1.612 & $* * *$ & -.380 & $* * *$ & -1.028 & $* * *$ \\
\hline HGZO & -.446 & $* * *$ & .541 & $* * *$ & 4.887 & $* * *$ & 1.367 & $* * *$ \\
\hline HSAO & .654 & $* * *$ & 2.066 & $* * *$ & 5.132 & $* * *$ & 2.706 & $* * *$ \\
\hline KUO & 1.510 & $* *$ & -.989 & & .922 & & 3.903 & $* * *$ \\
\hline geslacht: vrouw & .372 & $* * *$ & .881 & $* * *$ & 1.675 & $* * *$ & 1.291 & $* * *$ \\
\hline leeftijd & .020 & $* *$ & .099 & $* * *$ & .035 & $* * *$ & .039 & $* * *$ \\
\hline gem. eindexamencijfer & .019 & & .008 & & .158 & *** & .246 & $* * *$ \\
\hline Ervaring tijdens $\mathrm{HBO}$ opleiding & & & & & & & & \\
\hline relevante werkervaring & .059 & * & -.088 & & .077 & & .075 & \\
\hline bestuurlijke ervaring & -.144 & $* * *$ & -.051 & & -.445 & *** & -.039 & \\
\hline buitenlandervaring & -.122 & $* * *$ & -.526 & $* * *$ & -.340 & *** & -.200 & $* * *$ \\
\hline Oordeel selectiviteit opleiding & & & & & & & & \\
\hline Opleidingsgemiddelde & -.583 & $* * *$ & -.795 & $* * *$ & 1.511 & *** & -.321 & * \\
\hline individuele afwijking & -.034 & & -.061 & & .065 & * & -.003 & \\
\hline Competentieclusters & & & & & & & & \\
\hline specifieke kennis en vaardigheden & .088 & $* * *$ & .105 & $* * *$ & .463 & *** & .637 & $* * *$ \\
\hline academische vaardigheden & -.082 & * & .521 & $* * *$ & .261 & *** & -.048 & \\
\hline flexibiliteit & -.130 & *** & .025 & & -.243 & *** & .013 & \\
\hline innovatie en kennismanagement & .227 & $* * *$ & .221 & $* * *$ & -.014 & & .268 & $* * *$ \\
\hline zelf-management & .022 & & -.298 & $* * *$ & -.192 & *** & -.389 & $* * *$ \\
\hline interpersoonlijke vaardigheden & .144 & $* * *$ & .260 & $* * *$ & .341 & $* * *$ & .511 & *** \\
\hline $\begin{array}{l}\text { Commerc./ } \\
\text { ondernemerschapscompetenties }\end{array}$ & -.263 & $* * *$ & -.709 & $* * *$ & -.344 & *** & -.407 & $* * *$ \\
\hline buitenlandse talen & -.129 & $* * *$ & -.649 & $* * *$ & -.584 & *** & -.415 & *** \\
\hline
\end{tabular}

$\mathrm{N}=44.170$ 
Vrouwen zijn sterk geconcentreerd in sociaal, cultureel en onderwijsberoepen en verzorgende/medische beroepen. Oudere afgestudeerden werken ook vaker in laatstgenoemde richting. Cijfers versterken de kans op werk in sociaal, cultureel en onderwijsberoepen en verzorgende/medische beroepen. Het hebben van bestuurlijke ervaring verlaagt juist deze kans. Relevante werkervaring verlaagt de kans op werk in een natuur/ techniek beroep, terwijl buitenlandervaring de kans op werk in sociaal, cultureel en onderwijsberoepen verhoogt en van werk in verzorgende/medische beroepen verlaagt. Selectiviteit (opleidingsgemiddelde) verhoogt de kans dat men in een natuur/techniek beroep of een sociaal, cultureel of onderwijsberoep werkt, en verlaagt de kans dat men in een verzorgend/medisch beroep werkt.

Wat competenties betreft zien we nogmaals uiteenlopende effecten: specifieke kennis en vaardigheden en interpersoonlijke vaardigheden lijken het minst te worden gewaardeerd in de referentie beroepsrichting economische/administratieve beroepen. Bij de meeste andere generieke vaardigheden lijkt het tegenovergestelde waar te zijn.

Tabel 4 toont het effect van competenties en andere kenmerken op de kans dat men in verschillende bedrijfssectoren werkzaam is, ten opzichte van de kans op werk in de landbouw, industrie, energie en bouw.

Wat betreft onderwijssectoren liggen de sterkste effecten voor de hand: er zijn relatief veel HPO'ers in het onderwijs, HGZO'ers en HSAO'ers in de zorg, en HAO'ers en HTO'ers in de referentiebranche landbouw, industrie, energie en bouw. Omdat veel HEO'ers ook in deze branche werken zijn deze laatste effecten niet zo groot. Wellicht iets minder evident maar nog altijd niet geheel onverwacht is het hoog percentage HPO'ers in de zorg en het hoog aandeel HSAO'ers en KUO'ers in het onderwijs.

Vrouwen werken het minst vaak in de referentiebranche landbouw, industrie, energie en bouw, en het vaakst in de zorg en het onderwijs. Oudere afgestudeerden werken ook relatief weinig in de referentiebranche, en relatief vaak in het openbaar bestuur. Afgestudeerden met hoge cijfers werken relatief vaak in het onderwijs, en in iets minder mate in de zorg. Bestuurlijke ervaring en vooral buitenlandervaring lijkt de kans op werk in de referentie sector te vergroten, en de kans op werk in de zorg - en in het geval van buitenlandervaring het openbaar bestuur - te verkleinen. Relevante werkervaring lijkt weinig effect te hebben op de branche. Selectiviteit verhoogt vooral de kans op werk in de zorg, en in iets mindere mate de referentiebranche.

Specifieke kennis en vaardigheden, evenals interpersoonlijke vaardigheden, lijken de kans op werk in de zorg en het onderwijs te vergroten. Academische vaardigheden versterken de kans op werk in het openbaar bestuur, en in iets mindere mate de zorg. Zelf-management, commerciële/ ondernemerschapscompetenties en buitenlandse talen vergroten de kans op werk in de referentiebranche. 


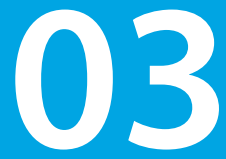

\section{VIGNETTENONDERZOEK ONDER WERKGEVERS}

Begin 2014 is door het ROA eenmalig een vignettenanalyse uitgevoerd onder ruim 500 werkgevers, in het kader van de jaarlijkse HBO Monitor. Deze studie richt zich op het verzamelen van informatie omtrent de arbeidsmarktintrede van hbo afgestudeerden, maar dan vanuit het perspectief van (potentiële) werkgevers. Er wordt gekeken welke informatie werkgevers gebruiken wanneer zij 1) een sollicitant uitnodigen voor gesprek en 2) een sollicitant aannemen als werknemer. Het onderzoek richt zich specifiek op de voorkeuren van werkgevers die nieuwe afgestudeerden van het hoger onderwijs rekruteren voor hun bedrijf of organisatie. Een van de attributen waarnaar is gevraagd is of de betreffende opleiding een honours- of excellentieprogramma of een ad-programma behelst. De uitkomsten van deze studie bieden derhalve interessante informatie wat betreft de betekenis van deze programma's voor werkgevers. Hieronder lichten we de studie nader toe.

Vignettenanalyse ('Conjoint Analyses') is een veel gebruikte methode voor het meten van preferenties van respondenten voor specifieke attributen van producten. Het geeft bijvoorbeeld inzicht in hoeverre de vraag naar een bepaald product of dienst gerelateerd is aan andere aspecten, zoals de prijs. In plaats van rechtstreeks te vragen waarom respondenten een bepaald product prefereren, of welke kenmerken van het product zij het belangrijkst vinden, maken vignettenstudies gebruik van een meer realistisch kader. Door respondenten voldoende verschillende profielen te laten evalueren of daaruit een keuze te laten maken, geven resultaten van vignettenstudies de waarde van bepaalde attributen van het product in relatie tot andere attributen.

Het grote voordeel van vignettenanalyse boven meer conventionele vormen van onderzoek is dat het respondenten dwingt om hun keuzes en preferenties expliciet te maken. In een traditionele enquête zouden werkgevers ongestraft kunnen aangeven dat ze aan alle denkbare attributen van afgestudeerden - het niveau en de richting van de gevolgde opleiding, de aanwezige werkervaring, de behaalde eindcijfers en zowel specifieke als generieke competenties - een zeer zwaar gewicht toekennen. Aan deze informatie hebben we echter weinig. In de praktijk moeten werkgevers meestal kiezen, omdat sollicitanten die op alle attributen als 'excellent' kunnen worden bestempeld praktisch onvindbaar zijn. In de meeste sollicitatieprocedures is sprake van een "trade-off", waarbij de werkgever aanvaardt dat de gekozen kandidaat iets minder goed scoort op 
bepaalde attributen, omdat die op de attributen die er echt toedoen wel tot de besten behoren. Vignettenanalyse dwingt werkgevers om zulke afwegingen expliciet te maken.

De vignettenstudie die begin 2014 heeft plaatsgevonden voorzag zoals gezegd in een opzet waarbij het selectieproces vanuit de werkgeverskant bespiegeld wordt: Stap 1) de keuze om een sollicitant uit te nodigen voor een gesprek en Stap 2) de keuze om een sollicitant aan te nemen. Daarnaast voorziet de studie in een korte achtergrondvragenlijst. Deze achtergrondvragenlijst bevat naast vragen over het bedrijf/de organisatie ook een vraag over de bekendheid van werkgevers met honours- of excellentieprogramma's en met ad-programma's. Deze informatie is op zichzelf al zeer relevant als peiling van de mate waarin werkgevers rekening houden met zulke programma's bij de werving en selectie van nieuw personeel, maar dient ook om de uitkomsten van de vignettenanalyse zelf te duiden.

Werkgevers werden via de bestaande werkgeverspanels van TNS Nipo voor de vignettenstudie geselecteerd. Hierbij werd geselecteerd op werkgevers die recent afgestudeerde hbo-ers en/of wo-ers in dienst hebben genomen voor geselecteerde beroepen. ${ }^{3}$ De keuze van de beroepen voor de vignettenstudie is daarbij gebaseerd op onder andere de uitkomsten van de HBO-Monitor met betrekking tot de beroepen waar afgestudeerden van het hbo in de eerste periode na het behalen van het diploma in terecht komen.

TABEL 5 CV-attributen in stap 1 van hypothetische sollicitatieprocedure

\begin{tabular}{|c|c|c|c|c|c|}
\hline \multirow{2}{*}{$\begin{array}{l}\text { Attributen } \\
\text { Opleiding }\end{array}$} & \multicolumn{5}{|c|}{ Onderscheiden niveau's } \\
\hline & $\begin{array}{r}\text { HB0 Associate } \\
\text { degree (Ad) }\end{array}$ & HBO Bachelor & WO Bachelor & W0 Master & \\
\hline $\begin{array}{l}\text { Aansluiting studierichting } \\
\text { bij functietaken }\end{array}$ & $\begin{array}{r}\text { Studierichting } \\
\text { sluit volledig } \\
\text { aan bij de } \\
\text { functietaken }\end{array}$ & $\begin{array}{r}\text { Studierichting } \\
\text { sluit gedeeltelijk } \\
\text { aan bij de } \\
\text { functietaken }\end{array}$ & $\begin{array}{l}\text { Studierichting } \\
\text { sluit niet aan bij } \\
\text { de functietaken }\end{array}$ & & \\
\hline $\begin{array}{l}\text { Relevante werkervaring } \\
\text { (incl. stages) }\end{array}$ & Geen & $1 / 2$ jaar & 1 jaar & 2 jaar & \\
\hline $\begin{array}{l}\text { Deel van de studie in het } \\
\text { buitenland gedaan? }\end{array}$ & Niet & Gedeeltelijk & Geheel & & \\
\hline Gemiddeld eindcijfer & 6 & 7 & 8 & 9 & \\
\hline $\begin{array}{l}\text { Excellentie-/ } \\
\text { honoursprogramma } \\
\text { gevolgd tijdens opleiding? }\end{array}$ & Nee & $\mathrm{Ja}$ & & & \\
\hline Bruto startsalaris: & $\begin{array}{r}25 \% \text { onder het } \\
\text { gemiddelde voor } \\
\text { deze functie }\end{array}$ & $\begin{array}{r}10 \% \text { onder het } \\
\text { gemiddelde voor } \\
\text { deze functie }\end{array}$ & $\begin{array}{r}\text { Gemiddeld voor } \\
\text { deze functie }\end{array}$ & $\begin{array}{r}10 \% \text { boven het } \\
\text { gemiddelde voor } \\
\text { deze functie }\end{array}$ & $\begin{array}{r}25 \% \text { boven het } \\
\text { gemiddelde voor } \\
\text { deze functie }\end{array}$ \\
\hline
\end{tabular}

In stap 1 van de vignettenanalyse zijn verschillende hypothetische profielen van mogelijke sollicitanten voorgelegd. De profielen zijn gebaseerd op karakteristieken die norma-

3 De respondenten zijn doorgaans niet de eigenaar of CEO van het bedrijf of de organisatie, maar een medewerker die in de afgelopen 5 jaar is betrokken bij de werving van nieuw personeel. 
liter in een motivatiebrief dan wel het CV opgenomen zijn, met daarbij een hypothetisch salariseis. Werkgevers wordt vervolgens gevraagd wie van de sollicitanten zij voor een sollicitatiegesprek zouden uitnodigen; van de drie profielen mogen ze slechts één sollicitant uitkiezen, of geen enkele. Dit keuzeproces wordt tien keer herhaald, met steeds andere combinaties van scores op de getoonde attributen. Tabel 5 toont de karakteristieken en de niveaus waarop sollicitanten onderscheiden konden worden.

Op basis van de gekozen profielen in elk van deze tien rondes is het mogelijk een preferentiescore toe te kennen aan elk niveau van alle getoonde attributen. Deze scores varieren tussen een paar punten onder nul tot een paar punten boven nul. Een score boven nul geeft aan dat de werkgever een positieve voorkeur heeft voor dit niveau van de betreffende attribuut, terwijl een negatieve score aangeeft dat de werkgever het betreffende niveau op de attribuut in kwestie liever zou willen vermijden. Per saldo tellen de preferentiescores voor de verschillende niveau's van een attribuut voor iedere respondent tot nul. Met andere woorden: als iemand een sterk positieve voorkeur heeft voor een bepaald niveau van een bepaald attribuut, moet deze persoon een negatieve voorkeur hebben voor minstens één ander niveau van dezelfde attribuut.

Algemeen geldt dat hoe meer de preferentiescores in absolute zin meer van de nullijn afwijken, hoe belangrijker dit attribuut is voor deze persoon. Er is immers dan een groter verschil tussen het meest geprefereerde niveau en het minst geprefereerde niveau op deze attribuut. Wanneer een attribuut in het geheel onbelangrijk is voor een respondent, zullen de preferentiescores voor alle niveau's op deze attribuut precies gelijk zijn aan nul. De mate waarin attributen belangrijk worden gevonden varieert zowel binnen respondenten tussen attributen, als tussen respondenten binnen elke attribuut.

Nadat de respondenten stap 1 hebben doorlopen volgt stap 2: de hypothetische sollicitatieprocedure: het daadwerkelijk aannemen van afgestudeerden van het hoger onderwijs op basis van hun competenties. Om de keuze voor een nieuwe werknemer zo realistisch mogelijk te maken wordt aan de werkgevers de volgende situatie voorgelegd:

Stelt u zich vervolgens voor dat u een groep kandidaten heeft geselecteerd en uitgenodigd, die allemaal even geschikt lijken voor de functie waar u voor werft. $U$ heeft deze kandidaten naar een assessmentcenter gestuurd, waar hun vaardigheidsniveau op de volgende zes gebieden grondig is getest:

- vakkennis en -vaardigheden

- algemene academische vaardigheden

- innovatieve vaardigheden

- $\quad$ strategische/organisatorische vaardigheden

- sociale vaardigheden

- commerciële vaardigheden.

Respondenten ontvangen definities van de competenties en krijgen nogmaals drie verschillende hypothetische profielen van mogelijke sollicitanten voorgelegd, nu met combinaties van deze zes competenties. ledere competentie kon varieren tussen drie niveau's, gebaseerd op de uitkomsten van de assessment: laagste $25 \%$, gemid- 
deld, en top $25 \%$. Werkgevers wordt vervolgens gevraagd wie van de sollicitanten zij zouden aannemen voor de baan; van de drie profielen mogen ze slechts één sollicitant uitkiezen, of geen enkele. Dit keuzeproces wordt tien keer herhaald. Nogmaals wordt op basis hiervan preferentiescores toegekend.

\subsection{Beschrijving van het werkgeversbestand ${ }^{4}$}

Voordat we de resultaten van de vignettenanalyses presenteren, is het nuttig om kort stil te staan bij de respondenten van het onderzoek en de organisaties die ze vertegenwoordigen. Tabel 6 geeft een overzicht van de kenmerken van de functie van de respondenten die aan het onderzoek hebben meegedaan.

TABEL 6 Kenmerken van de respondenten

\begin{tabular}{|r|r|}
\hline Functie respondent & $\%$ \\
\hline Algemeen manager & 45,2 \\
\hline HR manager, personeelsadviseur, recruiter & 12,7 \\
\hline Overig & 42,1 \\
\hline Afgelopen 5 jaar betrokken bij personeelswerving & 64,4 \\
\hline $1-5$ keer & 17,5 \\
\hline $6-10$ keer & 9,8 \\
\hline $11-25$ keer & 8,3 \\
\hline Meer dan 25 keer & \\
\hline
\end{tabular}

De overgrote meerderheid van de respondenten aan het onderzoek is algemeen manager of heeft een andere functie in de organisatie die niet specifiek gerelateerd is aan $H R$, personeelsmanagement e.d. Slechts één op de acht heeft een gespecialiseerde HR of personeelsfunctie. Dit is overigens eerder een voordeel dan een nadeel, omdat algemeen managers vermoedelijk beter op de hoogte zijn van de specifieke attributen die nodig zijn om goed te kunnen functioneren in de betreffende functie. De meeste respondenten zijn slechts incidenteel betrokken bij rekrutering van nieuw personeel.

Tabel 7 geeft een overzicht van de kenmerken van de organisatie waarin de respondent werkt. De respondenten zijn redelijk gespreid over organisaties van verschillende omvang, al zijn relatief kleine organisaties iets sterker vertegenwoordigd dan grotere organisaties. Vrijwel alle organisaties hebben HBO'ers in dienst. Ruim drie op de vijf heeft zowel HBO'ers als WO'ers in dienst, en nog eens een kleine derde heeft HBO'ers maar geen WO'ers. Slechts zo'n 4\% neemt alleen academici aan, en een vergelijkbaar percentage heeft geen hoger opgeleiden in dienst.

4 In totaal hebben 520 werkgevers meegedaan aan het onderzoek. Alle tabellen en figuren in deze paragraaf zijn op dit aantal gebaseerd. 
TABEL 7 Kenmerken van de organisatie

\begin{tabular}{|r|r|}
\hline Grootte(in NL) & $\%$ \\
\hline Minder dan 20 & 34,8 \\
\hline $20-49$ & 23,3 \\
\hline $50-99$ & 14,0 \\
\hline $100-249$ & 9,8 \\
\hline 250 of meer & 18,1 \\
\hline Hoger opgeleiden in dienst? & 60,4 \\
\hline Zowel HBO-ers als W0-ers & 4,2 \\
\hline Wel W0-ers maar geen HB0-ers & 31,9 \\
\hline Wel HBO-ers maar geen W0-ers & 3,5 \\
\hline Geen van beiden & \\
\hline
\end{tabular}

Tabel 8 laat de economische sector waarin de organisatie opereert zien. Hierop is expliciet geselecteerd bij het benaderen van potentiële respondenten, dus is niet erg verassend dat ook hier een goede spreiding te zien is. De sector "Financiële dienstverlening, bankwezen, verzekeringswezen" is iets sterker vertegenwoordigd dan de overige sectoren, terwijl "Media, communicatie" en "Juridische dienstverlening" minder sterk vertegenwoordigd zijn.

\section{TABEL 8 Economische sector}

\begin{tabular}{|r|r|}
\hline Financiële dienstverlening, bankwezen, verzekeringswezen & $\%$ \\
\hline Techniek, ICT, bouw & 8,3 \\
\hline Media, communicatie & 22,3 \\
\hline Juridische dienstverlening & 3,3 \\
\hline Overheid (nationaal, regionaal, lokaal) & 4,0 \\
\hline Gezondheid en welzijn & 5,2 \\
\hline Onderwijs & 9,0 \\
\hline Industrie & 6,9 \\
\hline Groothandel en detailhandel & 12,1 \\
\hline Overig & 12,5 \\
\hline
\end{tabular}

\subsection{De voorkeur voor cv-attributen}

Figuur 6 geeft een overzicht van de voorkeuren van werkgevers voor verschillende cv-kenmerken van afgestudeerden. Positieve voorkeuren geven aan dat ze positief tegenover het betreffende opleidingstype staan, terwijl negatieve voorkeuren als teken kunnen worden opgevat dat een werkgever liever het betreffende opleidingstype zouden willen vermijden. Hoewel er geen principiële boven- of ondergrens aan deze voorkeuren zit, variëren ze in de praktijk tussen ongeveer +5 en -5 (dit geldt ook voor de andere attributen, op een enkele uitschieter na). Voor presentatiedoeleinden maken we 
een onderscheid tussen de attributen waarvoor werkgevers een sterke voorkeur hebben (aansluiting tussen opleiding en functie, relevante werkervaring, gemiddeld eindcijfer en een lager startsalaris) eerst, in figuur $6 a$, en vervolgens de attributen waar werkgevers gemiddeld gesproken minder om geven (opleidingsniveau, studie in het buitenland en het hebben gevolgd van een excellentieprogramma), in figuur $6 \mathrm{~b}$. In de tweede figuur is de verticale as op slechts $1 / 4^{\mathrm{e}}$ van de schaal van de eerste figuur.

FIGUUR 6a CV-attributen waarvoor werkgevers een sterke voorkeur hebben

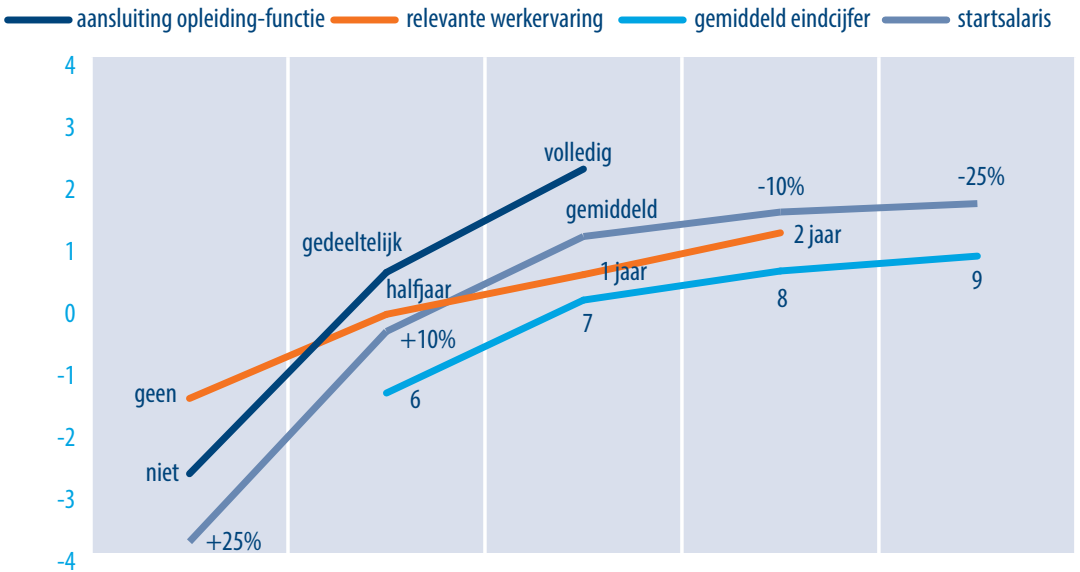

FIGUUR 6b CV-attributen waarvoor werkgevers een minder sterke voorkeur hebben*

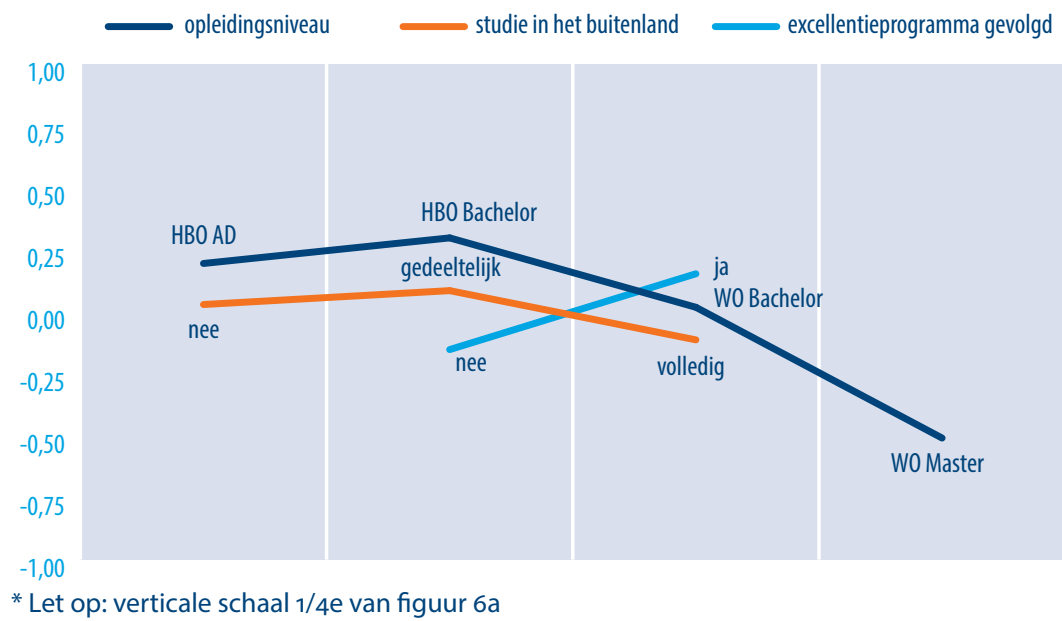

Uit figuur $6 a$ en b blijkt dat werkgevers vooral gespitst zijn op de aansluiting tussen studie en werk, relevante werkervaring, startsalaris en gemiddelde eindcijfers. Werkgevers lijken in het geheel niet in buitenlandervaring geïnteresseerd te zijn. Ze hebben een 
lichte voorkeur voor mensen die een excellentieprogramma hebben gevolgd in het kader van hun $\mathrm{HO}$-opleiding, maar het verschil is gering. Verassend genoeg lijken ze ook weinig te differentiëren tussen opleidingsniveau's in het hoger onderwijs. Voor zover als ze dat wel doen, komen HBO-bachelors en zelfs HBO Ad-programma's over de hele linie het beste uit de bus.

Het verschil ten opzichte van het WO zou echter niet moeten worden geïnterpreteerd als een hogere waardering voor HBO-ers en Ad-ers ten opzichte van WO-ers in het algemeen. Het is eerder een weerspiegeling van het feit dat in de Nederlandse markt voor hoger opgeleiden, het aandeel van HBO-banen groter is dan dat van WO-banen. Uit nader onderzoek blijkt tevens dat werkgevers slecht op de hoogte zijn van Ad-programma's, waardoor ze vermoedelijk geen onderscheid maken met reguliere HBO-bachelors. Zoals we straks zullen zien, zijn er wel specifieke groepen werkgevers die een duidelijke voorkeur voor academici hebben. Wel tonen de algemene resultaten aan dat er weinig sprake lijkt te zijn van verdringing van $\mathrm{HBO}$ - ers door WO-ers voor typische HBO-banen. Zelfs wanneer men de kans wordt aangeboden om een HBO-er te vervangen door een WO-er die in andere relevante opzichten gelijke kwalificaties heeft, wordt vaak nog de voorkeur gegeven aan de HBO-er.

Een opvallende uitkomst van de resultaten in figuren $6 \mathrm{a}$ en $6 \mathrm{~b}$ is het feit dat, voor attributen waarvoor een duidelijke richting is, de verschillen tussen een lage en een gemiddelde waarde veel groter is dan het verschil tussen gemiddeld en hoog. Dit is het meest geprononceerd voor startsalaris, maar een vergelijkbaar patroon is ook te zien voor aansluiting tussen opleiding en functie, relevante werkervaring en vooral het gemiddelde eindcijfer. De interpretatie lijkt te zijn dat er sprake is van afnemende meeropbrengsten voor de meeste cv-attributen. Blijkbaar willen de meeste werkgevers voorkomen dat ze iemand in dienst nemen met een lage waarde op het betreffende attribuut, maar als ze al verzekerd zijn dan de kandidaat in kwestie tenminste gemiddeld op het attribuut scoort, hebben ze er minder voor over om nog meer van hetzelfde attribuut te krijgen. In zekere zin is dit inherent aan de methode van de vignettenanalyses: werkgevers worden gedwongen on keuzes te maken, waarbij ze doorgaans alleen meer op één attribuut kunnen krijgen door in te leveren op één of meer andere attributen.

De verschillen tussen twee waarden op één attribuut zijn overigens direct vergelijkbaar met de verschillen tussen twee waarden op een ander attribuut. Hierdoor is mogelijk om na te gaan in hoeverre werkgevers bereid zouden zijn om iets in te leveren op het ene attribuut om iets meer te krijgen op het andere. Zo zien we bijvoorbeeld dat, zelfs wanneer ze al verzekerd zijn van een kandidaat wiens opleiding gedeeltelijk aansluit bij de functie, werkgevers over de hele linie bereid zouden zijn een zeker eindcijfer van zeven in te ruilen voor een magere zes, als ze daarbij verzekerd zouden zijn van een kandidaat met een opleiding die volledig bij de functie aansluit. Hieruit blijkt hoeveel belang men hecht aan het verkrijgen van een kandidaat met een goede aansluiting. Op een vergelijkbaar manier kunnen we concluderen dat werkgevers over de hele linie bereid zouden zijn om elk waarde op de in figuur $6 \mathrm{~b}$ getoonde attributen in te ruilen 
voor vrijwel ieder denkbare verbetering op één van de attributen in figuur $6 a$. Het is echter belangrijk te herinneren dat het hierbij om gemiddelde voorkeuren gaat. Het is niet uit te sluiten dat er specifieke werkgevers zijn die wel een sterke voorkeur hebben voor de attributen in figuur $6 \mathrm{~b}$. We komen later hierop terug.

Tenslotte een opmerking over de voorkeuren voor verschillende waarden van startsalaris. Het "afvlakkend" patroon is het meest geprononceerd voor dit attribuut: werkgevers willen een hoger dan gemiddeld salaris zeer graag vermijden, maar zijn weinig geïnteresseerd in de mogelijkheid om een salaris te betalen dat lager is dan gemiddeld. Het is aannemelijk dat tenminste een deel van dit effect op dezelfde manier uit te leggen als voor de overige attributen. De kostenbesparing als gevolg van het niet hoeven te betalen van een ongebruikelijk hoog salaris is zo groot dat men bereid zal zijn om veel in te leveren op andere attributen om dit te bewerkstelligen. Men kan zich eenvoudigweg niet veroorloven om zulke hoge salarissen te betalen. Andersom is het echter niet waard om nog verder in te leveren op andere attributen om een ongebruikelijk laag salaris te mogen betalen. De besparing weegt blijkbaar niet op tegen de lager verwachte productiviteit wanneer men substantieel moet inleveren op die andere attributen.

Er is echter een mogelijk ander verklaring dat voor een deel dit patroon zou kunnen verklaren. Hoewel werkgevers geïnstrueerd zijn om voor te stellen dat de kandidaten op alle niet-genoemde attributen gelijk zijn, is denkbaar dat men een aanbod van een sollicitant om voor een fors lager salaris te werken, als signaal opvat dat de kandidaat in kwestie niet geheel in orde is. Waarom zou de kandidaat immers zijn of haar diensten voor ver onder de marktprijs aanbieden wanneer hij/zij even goed is als de concurrentie? Als deze interpretatie juist is - of tenminste een deel van het patroon verklaard - is interessant om op te merken dat men de tegenovergestelde aanname niet geaccepteerd: dat mensen die zich voor een hoger loon aanbieden veel beter zijn dan de concurrentie. Waarschijnlijk worden zulke kandidaten eerder als brutaal aangemerkt en op die gronden afgewezen.

\subsection{De voorkeur voor competenties}

Figuur 7 toont de voorkeuren van werkgevers voor verschillende competenties. Hierbij wordt zoals gezegd ervan uitgegaan dat het om kandidaten die in termen van cv-kenmerken op zich geschikt zijn gevonden voor de baan. 


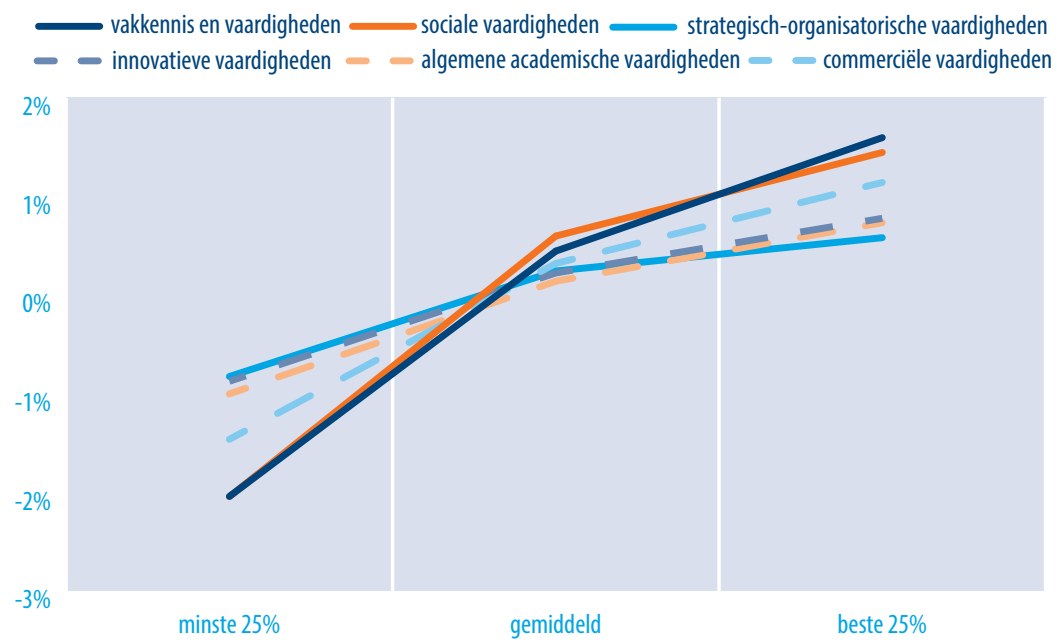

Hoewel werkgevers een duidelijk positieve voorkeur hebben voor alle genoemde competenties, komen vakkennis en -vaardigheden en sociale vaardigheden het sterkst naar voren als competenties waarin ze het sterkst geïnteresseerd zijn. Anders dan bij de cv-attributen zijn de verschillen in voorkeuren voor competenties niet zo extreem groot, en lijken werkgevers een positieve voorkeur te hebben voor alle zes competenties. Na vakkennis en -vaardigheden en sociale vaardigheden komen commerciële vaardigheden ook als relatief geliefd uit de bus. Een minder sterk maar nog altijd duidelijk positief voorkeur is te zien voor innovatieve, algemeen academische en strategischorganisatorische competenties.

Net als bij de cv-attributen lijken werkgevers meer gericht te zijn op het voorkomen van lage scores op deze competenties dan op het zich verzekeren van hogere scores. Toch zijn de verschillen tussen de competenties onderling zo groot dat we aan mogen nemen dat ze soms bereid zouden zijn een van de besten op één competentie te prefereren, al betekent dat dat ze een van de minsten op een andere competentie te accepteren. Dit is zeker het geval voor vakkennis. Als men de kans zou krijgen om iemand met een gemiddeld niveau van vakkennis in te ruilen voor iemand in de top $25 \%$, zouden ze over de hele linie bereid zijn om te accepteren dat deze persoon tot de laagste $25 \%$ behoort in termen van innovatieve, algemeen academische en strategisch-organisatorische competenties. De verschillen tussen gemiddeld en top $25 \%$ zijn iets minder sterk voor sociale en commerciële vaardigheden, waardoor men waarschijnlijk een additionele compensatie nodig zou hebben om een dergelijke ruil te accepteren. Overigens is bij sociale vaardigheden het verschil tussen gemiddeld en de laagste $25 \%$ erg groot in vergelijking met het verschil tussen gemiddeld en de top $25 \%$. Dit is niet zou vreemd: een werknemer met slechte sociale vaardigheden kan voor veel onrust zorgen in een bedrijf, en werkgevers willen heel begrijpelijk zulke kandidaten vermijden. Een kandi- 
daat met zeer goede sociale vaardigheden kan ook veel goeds voor de organisatie betekenen, maar het verschil zal in de meeste gevallen minder groot zijn.

Net als bij de cv-attributen is belangrijk om te benadrukken dat het hier om gemiddelde verschillen gaat. In de volgende paragraaf gaan we in op verschillen in voorkeuren naar organisatie- en functiekenmerken.

\subsection{Verschillen in voorkeuren naar organisatie- en functiekenmerken}

\section{Cv-attributen}

Het is interessant om na te gaan in hoeverre deze voorkeuren verschillen naar kenmerken van het bedrijf of de organisatie, en van de functie van de respondent. Om dit te doen hebben we een aantal multivariate analyses verricht, met als afhankelijke variabelen de voorkeuren voor cv-attributen, met als voorspellers een aantal organisatie- en functiekenmerken. Omdat het erg ingewikkeld zou zijn om analyses te verrichten op alle waarden van alle attributen, hebben we elk attribuut gereduceerd tot een verschilscore tussen twee waarden. In het geval van opleidingsniveau was dit het verschil tussen een HBO-bachelor en een WO-Master, en geeft derhalve de relatieve voorkeur aan voor een HBO'er boven een WO'er. In het geval van alle andere attributen was dit het verschil tussen de hoogste en de laagste waarde. Door de multivariate design wordt bij het schatten van alle effecten gecontroleerd voor het effect van alle andere organisatie- en functiekenmerken. Zo is bijvoorbeeld bij het schatten van het effect van het werkzaam zijn in een organisatie met (ook) WO'ers in dienst, al rekening gehouden met de functie waarvoor wordt gerekruteerd. Tabel 9 toont de resultaten van deze analyses. ${ }^{5}$

Zoals zou worden verwacht hangt de voorkeur voor HBO'ers versus academici af van de functie waarvoor wordt gerekruteerd. In vergelijking met de referentie categorie Financieel, HR of organisatieprofessional hebben de andere functiecategorieën een negatieve coëfficiënt. Hieruit blijkt dat de voorkeur voor HBO'ers het sterkste is in deze referentiefunctie. Werkgevers die een Juridisch of beleidsprofessional of een Sociaal, onderwijs of gezondheidszorg professional rekruteren hebben de sterkste voorkeur voor een academicus. Interessant is de bevinding dat na controle op functietype, geen van de andere kenmerken een effect hebben, ook niet de mate waarin werkgevers behalve HBO-ers ook WO-ers in dienst nemen.

De functie blijkt ook een belangrijke determinant van de voorkeur voor een goede aansluiting tussen opleiding en functie. In vergelijking met de referentiefunctie hechten werkgevers die een Media, marketing of sales professional of een Juridisch of beleids-

5 We hadden in eerste instantie ook kenmerken van de respondent in de analyses meegenomen (de functie bij het rekruteren van hoger opgeleiden). Deze kenmerken bleken nauwelijks van invloed te zijn op de voorkeuren. Om deze reden hebben we ze in de eindversie van de analyses achterwege gelaten. 
professional proberen te rekruteren, minder waarde aan deze aansluiting. Werkgevers in grote organisaties hebben ook een iets sterker voorkeur voor een goede aansluiting dan werkgevers in kleine organisaties. Dit effect is echter vrij klein en slechts op 10\% niveau significant.

Ook voor het attribuut relevante werkervaring zien we dat de functie de belangrijkste determinant is van verschillen. De effecten zijn echter in dit geval erg klein en maar net significant. In vergelijking met de referentiecategorie zien we een iets sterker voorkeur voor relevante werkervaring voor technische functies, en een iets zwakkere voorkeur voor juridische- of beleidsfuncties.

Zoals mag worden verwacht hebben organisaties die meer internationaal gericht zijn een sterkere voorkeur voor buitenlandervaring. Interessant is het feit dat werkgevers die voor juridische- of beleidsfuncties een iets sterker voorkeur hebben voor buitenlandervaring dan werkgevers die voor de referentiefunctie categorie Financieel, HR of organisatieprofessional rekruteren. Dit effect is echter niet zo sterk.

Wat betreft de voorkeur voor gemiddelde eindcijfers komt de functie weer naar voren als belangrijkste determinant. Werkgevers die rekruteren voor technische functies, of voor sociale, onderwijs of gezondheidszorgfuncties, hechten meer waarden aan cijfers dan werkgevers die voor de de referentiefunctie rekruteren. Ook organisaties die op nationaal en vooral op internationaal niveau opereren, hebben een sterkere voorkeur voor cijfers dan werkgevers die enkel of regionale of lokale niveau opereren.

De voorkeur voor excellentieprogramma's komt het sterkst naar voren in grote organisaties. Dit was wellicht te verwachten, omdat zulke organisaties meer ruimte hebben voor sterke gedifferentieerde loopbaanplannen waarmee recht zou kunnen worden gedaan aan de specifieke eigenschappen van mensen die tijdens het $\mathrm{HO}$ zo'n excellentieprogramma hebben gevolgd. Het is ook waarschijnlijk dat werkgevers in grote organisaties meer ervaring met excellentiestudenten hebben, en daarmee een duidelijker idee van wat ze ermee aankunnen. Er is ook een positief effect voor werkgevers die op het nationaal niveau opereren (in vergelijking met werkgevers die enkel of regionale of lokale niveau opereren), maar dit effect is zwak en nauwelijks significant. Interessant is het feit dat dit het enige attribuut waarvoor de voorkeur in het geheel niet door de functie wordt beïnvloedt. 


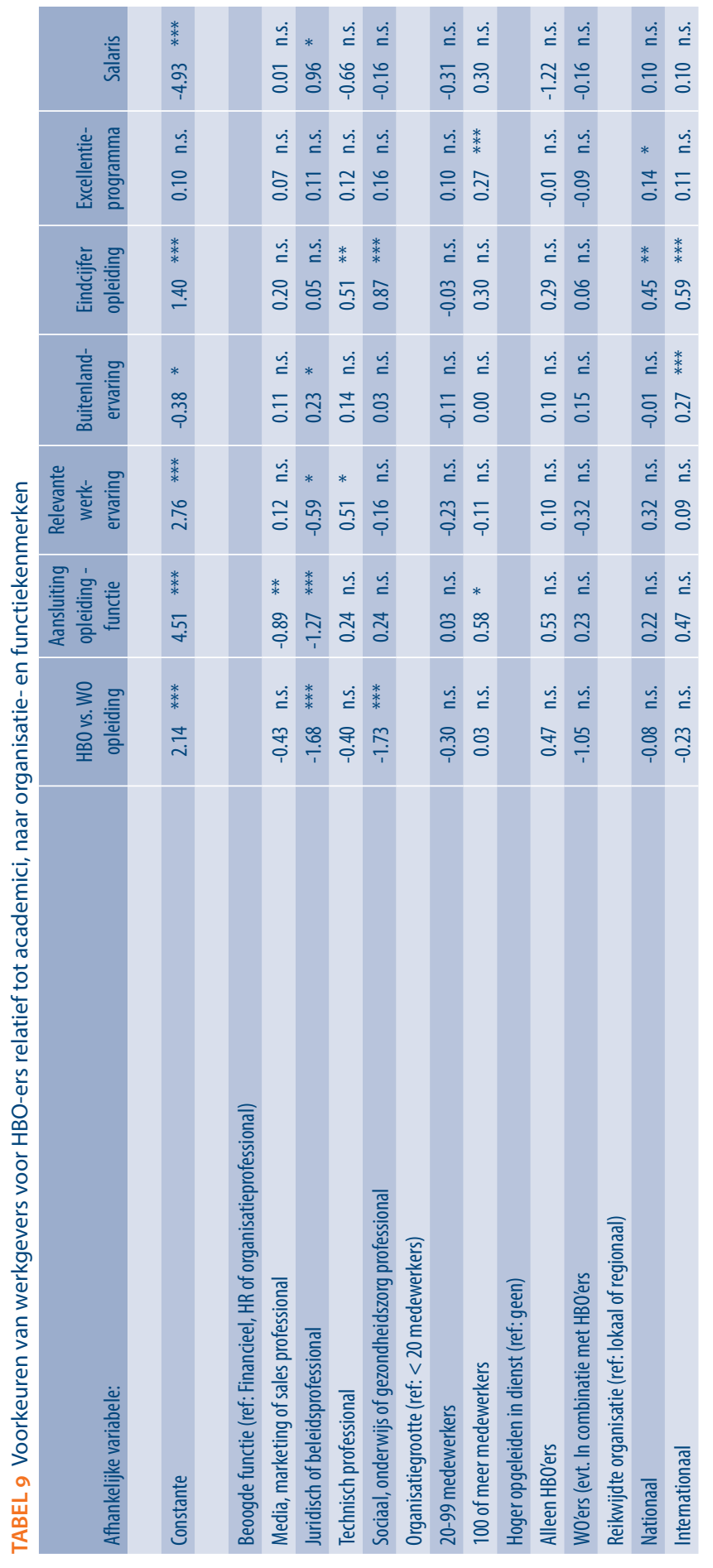


Tenslotte zien we dat, hoewel over de hele linie werkgevers graag willen vermijden dat ze een salaris betalen dat boven de marktprijs is, dit nauwelijks samenhangt met kenmerken van de functie of organisatie. We zien alleen een zwak effect voor werkgevers die selecteren voor juridische- of beleidsfuncties, in vergelijking met de referentiecategorie. Werkgevers die voor deze functies rekruteren zijn iets minder gespitst op het voorkomen van hoge salarissen dan werkgevers die voor andere functies rekruteren. Uit de grootte van de coëfficiënt kan echter worden opgemaakt dat ook deze werkgevers liefst geen hoge salarissen betalen. De coëfficiënt bedraagt net iets minder dan 1, terwijl over de hele linie het verschil tussen $25 \%$ boven gemiddeld en $25 \%$ onder gemiddeld salaris bijna 5,5 punten bedraagt.

\section{Competenties}

Tabel 10 toont de resultaten voor een vergelijkbaar serie multivariate analyses, nu met de voorkeuren voor competenties als afhankelijke variabelen. Ook hier wordt het verschil tussen de beste en de minste waarde genomen als afhankelijke variabele in alle gevallen.

De voorkeur voor vakkennis lijkt vrijwel universeel te zijn. De enige uitzondering betreft media-, marketing- of salesfuncties. Voor deze functies wordt vakkennis beduidend minder belangrijk gevonden dan voor alle andere functies.

Ook voor algemene academische vaardigheden blijkt dat ze minder belangrijk worden gevonden in media-, marketing- of salesfuncties. In absolute zin is het effect minder groot, maar als we bedenken dat deze algemene vaardigheden in het geheel minder belangrijk worden gevonden dan vakkennis, is het effect van betekenis, omdat het betekent dat de voorkeur onder werkgevers die voor deze functies rekruteren tamelijk zwak is. Interessant genoeg zien we dat in organisaties die op nationaal of internationaal niveau opereren, algemene academische vaardigheden belangrijker worden gevonden dan in organisaties die enkel op lokaal of regionaal niveau opereren.

Innovatieve vaardigheden worden ook relatief belangrijk gevonden in organisaties die op nationaal of internationaal niveau opereren. Ook werkgevers die voor technische of sociale, onderwijs of gezondheidszorgfuncties rekruteren vinden deze competentie relatief belangrijk. Er is ook een effect voor grote organisaties, maar dit effect is tamelijk zwak.

Strategisch-organisatorische vaardigheden toont van alle competenties de meeste verschillen naar organisatie- en functiekenmerken in termen van voorkeuren. Ze worden minder belangrijk worden gevonden in media-, marketing- of salesfuncties, en iets belangrijker in sociale, onderwijs of gezondheidszorgfuncties. Zoals mag worden verwacht wordt meer op zulke vaardigheden gelet in middelgrote en grote organisaties dan in kleine organisatie, hoewel de effecten niet zo heel erg sterk zijn. Ten opzichte van 
organisatie die enkel op lokaal of regionaal niveau opereren worden deze competenties relatief sterk gewaardeerd in organisaties die op nationaal niveau opereren.

Net als vakkennis lijkt de voorkeur voor sociale vaardigheden nogal breed gedragen door verschillende soorten werkgevers. De voorkeur lijkt sterker te zijn onder werkgevers die voor sociale, onderwijs of gezondheidszorgfuncties rekruteren, en in iets mindere mate in middelgrote organisaties.

We hebben gezien dat de voorkeur voor een aantal competenties - vakkennis, innovatieve en strategisch-organisatorische vaardigheden - lager is onder werkgevers die voor media-, marketing- of salesfuncties rekruteren dan voor andere functies. Bij commerciële vaardigheden zien we het tegenovergestelde. Deze vaardigheden worden veel sterker gewaardeerd voor zulke functies dan voor de referentiefunctie. Datzelfde geldt, zij het in veel mindere mate, voor technische functies. We zien geen andere significantie effecten op de voorkeur voor commerciële vaardigheden. 


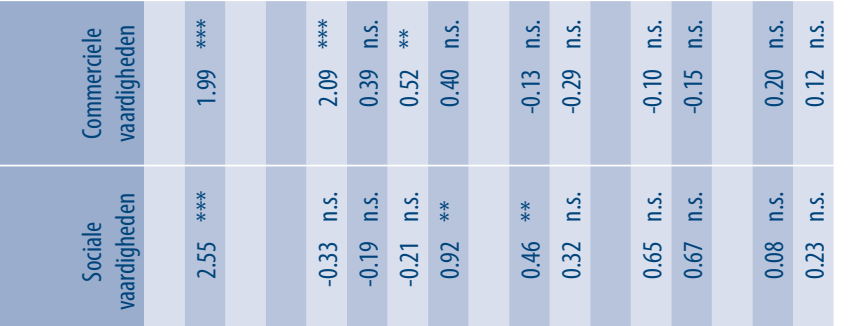

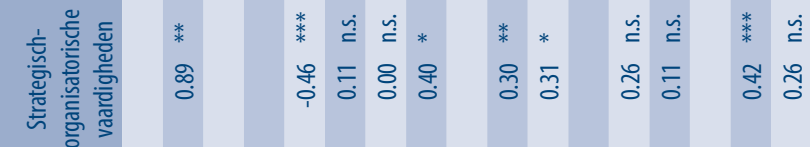

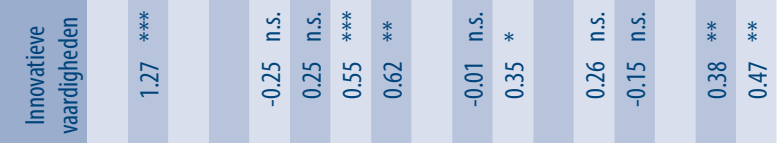

\begin{tabular}{|c|c|c|c|c|c|c|c|c|c|c|}
\hline 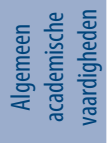 & \begin{tabular}{l}
$*$ \\
\multirow{2}{*}{} \\
8 \\
0
\end{tabular} & & 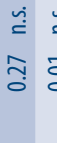 & & 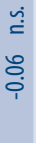 & $\begin{array}{l}\stackrel{\dot{S}}{=} \\
\stackrel{+}{0}\end{array}$ & $\begin{array}{l}\stackrel{\vec{d}}{=} \\
\hat{0}\end{array}$ & $\begin{array}{l}\stackrel{\dot{S}}{=} \\
\text { fo }\end{array}$ & ơ & $\begin{array}{l}\text { * } \\
\text { 年 } \\
\text { f }\end{array}$ \\
\hline 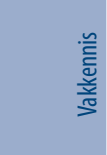 & $\begin{array}{l}\text { * } \\
* \\
\stackrel{8}{9} \\
\end{array}$ & $\begin{array}{l}\text { *⿻ } \\
* \\
\stackrel{\rightarrow}{i}\end{array}$ & $\begin{array}{l}\dot{\mathfrak{g}} \\
\bar{c} \\
\bar{\sigma} \\
\dot{\varphi}\end{array}$ & 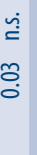 & 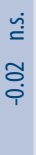 & $\begin{array}{l}\stackrel{u}{\check{c}} \\
\hat{0} \\
\dot{\phi}\end{array}$ & 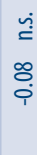 & 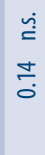 & 8 & $\begin{array}{l}\dot{\mathfrak{d}} \\
\dot{J} \\
\dot{J}\end{array}$ \\
\hline
\end{tabular}

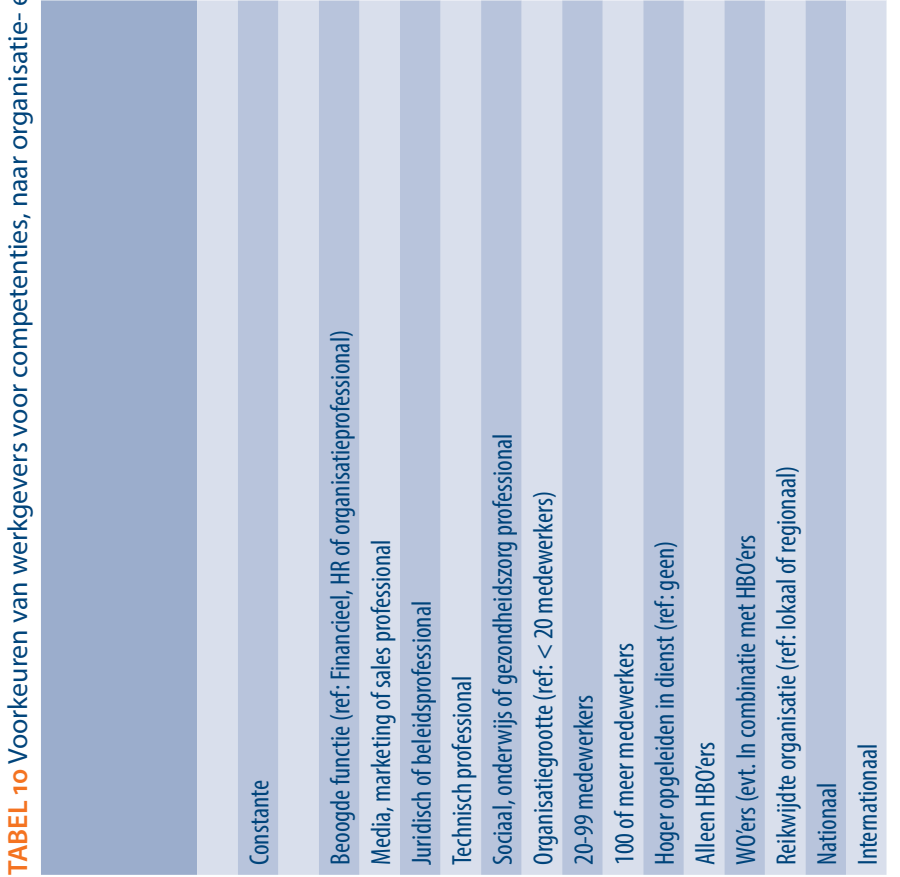





\section{4 \\ CONCLUSIES}

In dit rapport hebben we de voorkeuren van werkgevers voor hoger opgeleiden vanuit twee verschillende perspectieven te belichten. Eerst hebben we de data van de HBO monitor gebruikt, maar op een andere manier dan gebruikelijk is in de jaarlijkse landelijke rapporten van de $\mathrm{HBO}-M o n i t o r$. We hebben gekeken naar de mate waarin verschillende kenmerken van de afgestudeerden een voorspellende waarde hebben op de kans dat men werkzaam is binnen hun kerndomein. Hierdoor hopen we zicht te krijgen op de kenmerken waarop werkgevers letten wanneer ze HBO'ers rekruteren voor de functies waarvoor ze worden opgeleid. Ten tweede hebben we resultaten gepresenteerd uit een recent onderzoek onder werkgevers, waarbij de methode van vignettenanalyse is toegepast.

Uit de analyses op de HBO-Monitor data komt een aantal resultaten naar voren, een aantal daarvan zijn redelijk bekend, maar een aantal misschien iets minder bekend. Weinig verassend waren de grote verschillen tussen HBO opleidingssectoren in termen van kansen op werk binnen het eigen kerndomein. Bijna de helft van de afgestudeerden van de sectoren HSAO, KUO en HEO die zich op de arbeidsmarkt aanbieden komt buiten het eigen kerndomein terecht. Dit geldt voor slechts ongeveer een kwart van de HTO'ers en HGZO'ers, en iets meer dan één op de zes HPO'ers.

Vrouwen werken even vaak als mannen buiten de eigen of verwante richting op HBO niveau, maar hebben een veel grotere kans om onder HBO niveau te werken. Bij oudere afgestudeerden is juist het risico op werk buiten de eigen richting groter dan bij jongere afgestudeerden. Goede eindcijfers lijken in alle opzichten sterk te differentiëren in termen van de kans op werk binnen of buiten het eigen kerndomein.

Zoals zou worden verwacht verlaagt relevante werkervaring de kans op werk buiten de eigen opleidingsrichting, zowel op HBO-niveau als daaronder. Echter, zulke ervaring verhoogt de kans op werk onder het eigen niveau maar binnen de eigen of verwante richting. Dit laatste effect kan een gevolg zijn van het feit dat sommige afgestudeerden na afstuderen blijven werken in dezelfde baan als ze tijdens de opleiding hadden.

Selectiviteit van de opleiding heeft zoals verwacht een sterk effect op de kans op werk binnen het kerndomein. Bewust of onbewust lijken werkgevers die banen aanbieden die 
zowel naar niveau als naar richting aansluiten bij de opleiding van de afgestudeerden, een sterke voorkeur te hebben voor afgestudeerden van selectievere opleidingen. Dit lijkt vooral te gelden voor de kans op werk binnen de eigen of verwante opleidingsrichting. Dit effect is overigens alleen te zien in de multivariate analyses, en alleen voor het opleidingsgemiddelde op de schaal. Gezien het feit dat selectiviteit bij uitstek een opleidingskenmerk is, is dit niet erg verassend. De individuele afwijking van dit gemiddelde is vermoedelijk vooral een negatieve indicator van het eigen competentieniveau, en heeft derhalve een versterkende effect op de kans op werk onder HBO-niveau, zowel binnen als buiten de eigen richting.

Wat betreft competenties, zijn de sterkste effecten te zien voor specifieke kennis en vaardigheden en academische vaardigheden, vooral de eerstgenoemde. Anders dan de meer generieke vaardigheden heeft specifieke kennis en vaardigheden naast een sterk remmend effect op de kans op werk onder eigen niveau ook een remmend effect op de kans op werk buiten de eigen of verwante richting.

Uit de vignettenanalyses komt naar voren dat van alle cv-attributen werkgevers vooral gespitst zijn op de aansluiting tussen studie en werk, relevante werkervaring, startsalaris en gemiddelde eindcijfers. Werkgevers lijken in het geheel niet in buitenlandervaring geïnteresseerd te zijn. Ze hebben een lichte voorkeur voor mensen die een excellentieprogramma hebben gevolgd in het kader van hun HO-opleiding, maar het verschil is gering. Verassend genoeg lijken ze ook weinig te differentiëren tussen opleidingsniveau's in het hoger onderwijs. Voor zover als ze dat wel doen, komen HBO-ers over de hele linie het beste uit de bus. Dit verschil ligt vermoedelijk aan de verdeling van $\mathrm{HBO}$ versus WO functies in de Nederlandse economie, en dient niet te worden geïnterpreteerd als een hogere waardering voor HBO-ers ten opzichte van WO-ers in het algemeen. Wel tonen de algemene resultaten aan dat er weinig sprake lijkt te zijn van verdringing van $\mathrm{HBO}$ - ers door WO-ers voor typische $\mathrm{HBO}$-banen.

Werkgevers hebben een duidelijk positieve voorkeur voor alle gepresenteerde competenties, maar vakkennis en -vaardigheden en sociale vaardigheden komen het sterkst naar voren als competenties waarin ze het sterkst geïnteresseerd zijn. Ook commerciële vaardigheden komen als relatief geliefd uit de bus. Een minder sterk maar nog altijd duidelijk positieve voorkeur is te zien voor innovatieve, algemeen academische en strategisch-organisatorische competenties.

Wanneer we deze resultaten vergelijken met de HBO-Monitor, zien we dat de werkgevers het belang van specifieke kennis en vaardigheden bevestigen. In andere opzichten zien we echter belangrijke verschillen. Werkgevers hechten veel waarde aan sociale vaardigheden, terwijl recente afgestudeerden aangeven dat het vereiste niveau van interpersoonlijke vaardigheden relatief weinig onderscheidt tussen banen binnen of buiten het eigen kerndomein. Andersom blijken werkgevers relatief weinig waarde te hechten aan algemene academische vaardigheden, terwijl afgestudeerden aangeven dat ze sterk differentiëren, tenminste wat de kans op werk op minimaal HBO betreft. Het 
is niet meteen evident wat deze verschillen betekenen, maar enkele kanttekeningen zijn op hun plaats. Ten eerste kunnen we niet zo maar aannemen dat werkgevers en afgestudeerden deze competenties gelijk definiëren. Ten tweede, in beide gevallen worden de competenties gewaardeerd, het gaat slechts om accentverschillen. Het is echter ook mogelijk dat er een ingebouwde bias is, waarbij werkgevers de consequenties van het hebben van slechte sociale vaardigheden in hun dagelijks werk zien, terwijl respondenten er wellicht iets minder op gespitst zijn, en meer op de in hun ogen belangrijke academische vaardigheden.

Zoals zou worden verwacht hangt de voorkeur voor HBO'ers versus academici af van de functie waarvoor wordt gerekruteerd. De voorkeur voor HBO'ers blijkt het sterkste te zijn in financiële-, HR- of organisatiefuncties. Werkgevers die een juridisch of beleidsprofessional of een sociaal, onderwijs of gezondheidszorg professional rekruteren hebben de sterkste voorkeur voor een academicus.

Werkgevers die een media, marketing of sales professional of een juridisch of beleidsprofessional proberen te rekruteren, hechten minder waarde aan de aansluiting tussen studie en werk. Werkgevers in grote organisaties hebben juist een iets sterkere voorkeur voor een goede aansluiting dan werkgevers in kleine organisaties. Ook voor het attribuut relevante werkervaring zien we dat de functie de belangrijkste determinant is van verschillen, al zijn de effecten erg klein. We zien een iets sterker voorkeur voor relevante werkervaring voor technische functies, en een iets zwakkere voorkeur voor juridische- of beleidsfuncties.

Zoals mag worden verwacht hebben organisaties die meer internationaal gericht zijn een sterkere voorkeur voor buitenlandervaring. Interessant is het feit dat werkgevers die voor juridische- of beleidsfuncties een iets sterkere voorkeur hebben voor buitenlandervaring dan werkgevers die voor de referentiefunctie categorie Financieel, HR of organisatieprofessional rekruteren. Dit effect is echter niet zo sterk.

Gemiddelde eindcijfers worden relatief belangrijk gevonden onder werkgevers die voor technische functies, of voor sociale, onderwijs of gezondheidszorgfuncties rekruteren. Ook organisaties die op nationaal en vooral op internationaal niveau opereren, hebben een sterkere voorkeur voor cijfers dan werkgevers die enkel op het regionale of lokale niveau opereren. De voorkeur voor excellentieprogramma's komt het sterkst naar voren in grote organisaties. Tenslotte zien we dat, hoewel over de hele linie werkgevers graag willen vermijden dat ze een salaris betalen dat boven de marktprijs is, dit nauwelijks samenhangt met kenmerken van de functie of organisatie.

Wat competenties betreft lijkt de voorkeur voor vakkennis vrijwel universeel te zijn, met als enige gedeeltelijke uitzondering media-, marketing- of salesfuncties. Ook algemene academische vaardigheden blijken minder belangrijk te worden gevonden in deze functies. Interessant genoeg zien we dat in organisaties die op nationaal of internationaal 
niveau opereren, algemene academische vaardigheden belangrijker worden gevonden dan in organisaties die enkel op lokaal of regionaal niveau opereren.

Innovatieve vaardigheden worden ook relatief belangrijk gevonden in organisaties die op nationaal of internationaal niveau opereren. Ook werkgevers die voor technische of sociale, onderwijs of gezondheidszorgfuncties rekruteren vinden deze competentie relatief belangrijk. Er is ook een effect voor grote organisaties, maar dit effect is tamelijk zwak.

Strategisch-organisatorische vaardigheden tonen van alle competenties de meeste verschillen naar organisatie- en functiekenmerken in termen van voorkeuren. Ze worden minder belangrijk gevonden in media-, marketing- of salesfuncties, en iets belangrijker in sociale, onderwijs of gezondheidszorgfuncties. Zoals mag worden verwacht wordt meer op zulke vaardigheden gelet in middelgrote en grote organisaties dan in kleine organisatie, hoewel de effecten niet zo heel erg sterk zijn. Ten opzichte van organisatie die enkel op lokaal of regionaal niveau opereren worden deze competenties relatief sterk gewaardeerd in organisaties die op nationaal niveau opereren.

Net als vakkennis lijkt de voorkeur voor sociale vaardigheden nogal breed gedragen door verschillende soorten werkgevers. De voorkeur lijkt sterker te zijn onder werkgevers die voor sociale, onderwijs of gezondheidszorgfuncties rekruteren, en in iets mindere mate in middelgrote organisaties.

We hebben gezien dat de voorkeur voor een aantal competenties - vakkennis, innovatieve en strategisch-organisatorische vaardigheden - lager is onder werkgevers die voor media-, marketing- of salesfuncties rekruteren dan voor andere functies. Bij commerciële vaardigheden zien we het tegenovergestelde. Deze vaardigheden worden veel sterker gewaardeerd voor zulke functies dan voor de referentiefunctie. Datzelfde geldt, zij het in veel mindere mate, voor technische functies. We zien geen andere significantie effecten op de voorkeur voor commerciële vaardigheden. 


\section{LITERATUUR}

J. Allen, R. van der Velden (2013), Skills for the 21st Century: Implications for Dutch Education, In: L.R. Smith (ed.), Higher Education: Recent Trends, Emerging Issues and Future Outlook, New York: Nova Science Publishers, pp. 1-40.

Akyeampong, Ernest B. (1992). “Discouraged workers - where have they gone?" Perspectives on Labour and Income. 3 (Canada: Statistics Canada) 4 (Article 5). 
